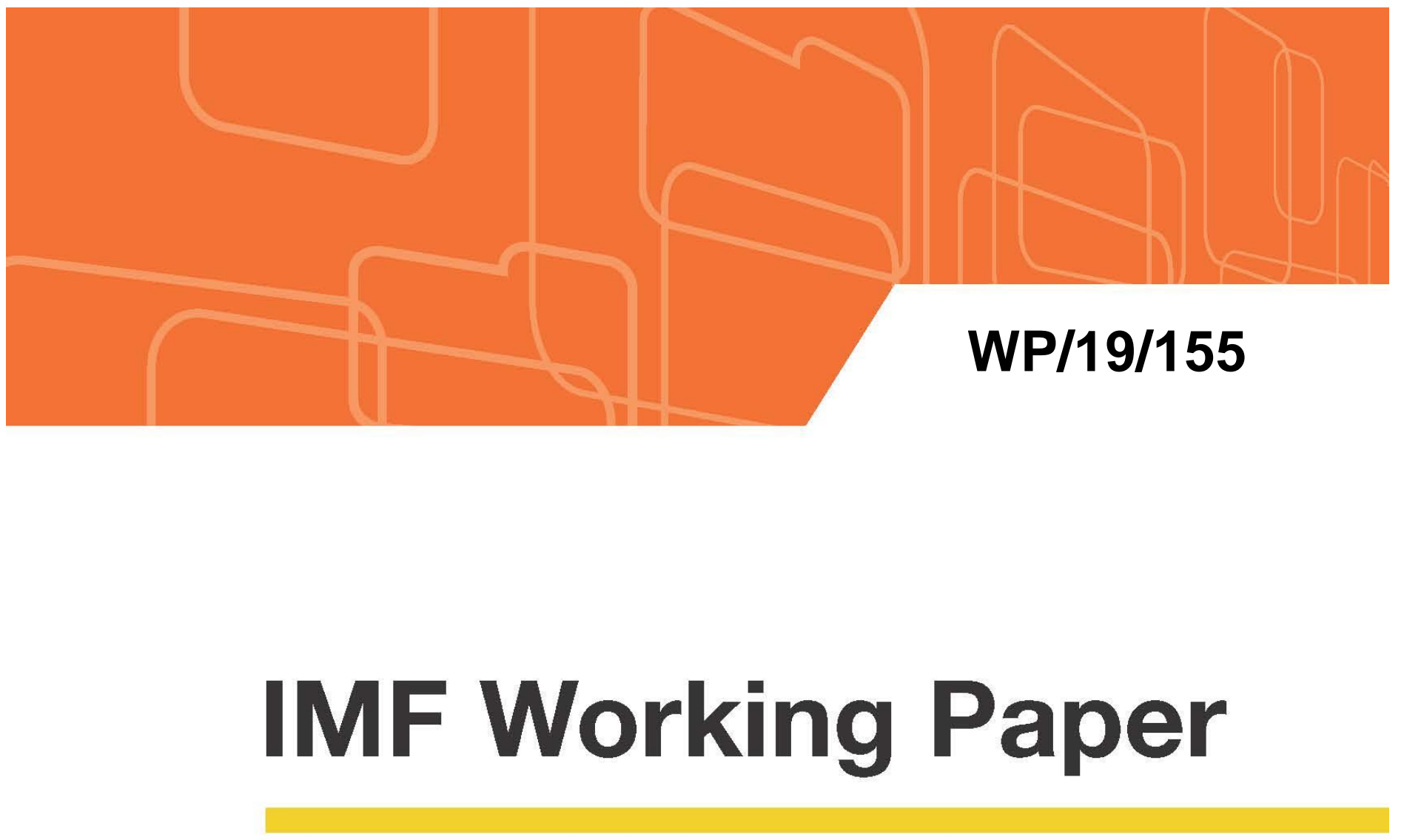

\title{
Impacts of Labor Market Institutions and Demographic Factors on Labor Markets in Latin America
}

\author{
by Professor Adriana D. Kugler
}

IMF Working Papers describe research in progress by the author(s) and are published to elicit comments and to encourage debate. The views expressed in IMF Working Papers are those of the author(s) and do not necessarily represent the views of the IMF, its Executive Board, or IMF management. 


\title{
IMF Working Paper
}

Western Hemisphere Department

\section{Impacts of Labor Market Institutions and Demographic Factors on Labor Markets in Latin America ${ }^{1}$}

\section{Prepared by Professor Adriana D. Kugler ${ }^{2}$}

Authorized for distribution by Jorge Roldos

July 2019

\section{IMF Working Papers describe research in progress by the author(s) and are published to elicit comments and to encourage debate. The views expressed in IMF Working Papers are those of the author(s) and do not necessarily represent the views of the IMF, its Executive Board, or IMF management.}

\begin{abstract}
This paper documents recent labor market performance in the Latin American region. The paper shows that unemployment, informality, and inequality have been falling over the past two decades, though still remain high. By contrast, productivity has remained stubbornly low. The paper, then, turns to the potential impacts of various labor market institutions, including employment protection legislation (EPL), minimum wages (MW), payroll taxes, unemployment insurance (UI) and collective bargaining, as well as the impacts of demographic changes on labor market performance. The paper relies on evidence from carefully conducted studies based on micro-data for countries in the region and for other countries with similar income levels to draw conclusions on the impact of labor market institutions and demographic factors on unemployment, informality, inequality and productivity. The decreases in unemployment and informality can be partly explained by the reduced strictness of EPL and

\footnotetext{
${ }^{1}$ I would like to thank Gabriel Barbosa for excellent research assistance. I would also like to thank Jorge Roldos, Roberto Cardarelli, Romain Duval as well as participants in the IMF Western Hemisphere seminar for helpful comments and the Western Hemisphere of the International Monetary Fund for Research Support.

${ }^{2}$ McCourt School of Public Policy, Old North, Suite 311, 37 th and O Streets, N.W., Washington, D.C. 200057. E-mail: adriana.kugler@georgetown.edu.
} 
payroll taxes, but also by the increased shares of more educated and older workers. By contrast, the fall in inequality starting in 2002 can be explained by a combination of binding MW throughout most of the region and, to a lesser extent, by the introduction of UI systems in some countries and the role of unions in countries with moderate unionization rates. Falling inequality can also be explained by the fall in the returns to skill associated with increased share of more educated and older workers.

JEL Classification Numbers: J2, E2, E26, N36

Keywords: labor market institutions, labor demographics, inequality, Latin America.

Author’s E-Mail Address: adriana.kugler@georgertown.edu 


\section{INTRODUCTION}

Over the past few decades, labor markets in Latin America have become more flexible, with labor market regulations becoming less strict in certain areas. However, these changes have not fully translated into better labor market performance in Latin American Countries (LAC), perhaps partly due to cyclical forces and commodity price busts. Figure 1 shows that the unemployment rate has been declining since the 2000s. The unemployment rate in LAC was much higher than the average unemployment rate in OECD countries up until 2009. However, during the Great Recession the unemployment rate actually fell below the unemployment rate in the U.S., Canada and the OECD from 2010 to 2014. Though the unemployment rate increased again in 2015 and 2016, the unemployment rate in the region remains below where it was in the early 2000s. Informality has also been declining steadily as shown in Figure 3. However, on average, half of overall employment in the region remains in the informal sector. The declines in unemployment and informality, as discussed in this paper, are probably explained partly by demographic changes towards more skilled workers but also by reductions in payroll taxes and the relaxation of employment protections during this period.

Figure 5 shows, however, that productivity in the region is many magnitudes lower than labor productivity in the U.S. and Canada and that productivity has barely budged over the past two decades in the region.

Why has labor market performance remained disappointing in the region? First, while some labor market institutions have become less strict, others have only been relaxed on the margins. Second, weakening labor market regulations may not always be good for labor market performance. While labor market regulations may have unintended negative consequences in some dimensions, they may actually be positive for workers and the functioning of the labor market on other dimensions. In particular, labor market institutions can help to protect workers by increasing earnings and lifting them out of poverty. Moreover, labor market institutions may help to correct market imperfections that arise in the labor market.

An unequivocally positive development has been the fall in inequality in Latin America over the past few decades. Figure 7 shows the average Gini coefficient in Latin America, Africa, Asia, Western Europe and North America and Eastern Europe. The Gini in LAC is a lot higher than in all other regions. Only inequality in Africa is comparable to that of Latin America during the last decade. While inequality in the region is still high, though, inequality has been falling since the past two decades. This may be in part the result of the, still, highly protective labor market legislation in place, which places wage floors, and also partly the result of lower returns to skills in the labor market, as discussed below.

Unfortunately, similar to European countries, the high unemployment may also be partly due to the still strict labor market regulations in LAC. In addition, in the Latin American context, where enforcement is lax, informality is another manifestation of strict regulations. In turn, high informal activity can lead to low productivity due to small scale and little capital investment.

This paper focuses on factors affecting demand for formal employment in Latin America. In particular, this paper reviews the state of various labor market institutions, including employment 
protection legislation (EPL), minimum wages (MW), payroll taxes, unemployment insurance (UI) and collective bargaining on informality, productivity and employment. Then, I discuss the impact of various supply side factors, including the supply of skilled vs. unskilled workers, the supply of younger vs. older workers and the supply of female vs. male workers.

In Section 2 of the paper, I will give an overview of the state of Latin American labor markets. In Section 3, I will describe the regulatory environment in Latin America with regards to EPL, MW, payroll taxes, UI and collective bargaining. I will also review the literature on the impacts of these various regulations on wages, unemployment, informality and productivity. In Section 4, I will turn to consider how demographic characteristics (including, education, age and gender) contribute to inequality and unemployment in the Latin American context. I conclude in Section 5.

\section{OVERVIEW OF LABOR MARKETS IN LATIN AMERICAN}

As shown in Figure 1, the average unemployment rate in Latin America is almost 3 percentage points higher than in the U.S. and Canada. The unemployment rate, however, varies widely across Latin America. Figure 2 shows that Brazil has an unemployment rate, reaching $12.9 \%$ overall and $15.1 \%$ for women and $11.2 \%$ for men. By contrast, Guatemala and Cuba have unemployment rates just above $2 \%$. The overall unemployment rate in Cuba is $2.6 \%$, while the unemployment for women in Cuba is $3 \%$ and $2.3 \%$ for men. The unemployment rate in most countries in the region, though, is much higher than the current $4.6 \%$ in the U.S. Only Honduras, Nicaragua, Peru, Mexico, Bolivia, Guatemala and Cuba have lower unemployment rates than the average in the U.S. and Canada. ${ }^{3}$ The average overall unemployment rate in the region is $8.2 \%$, and $9.9 \%$ for women and $7.1 \%$ for men. As shown in Figure 1, this unemployment rate is lower than it was in the early 2000s and has been on a downward trend in the past two decades. However, this does not necessarily reflect healthy labor markets in these countries. As we will see below, this may instead reflect the fact that these countries have high levels of informality. Thus, labor markets in these countries may, instead, be characterized by under-employment or hidden unemployment. Countries with relatively lower informality such as Brazil, Costa Rica, Argentina and Venezuela have higher unemployment rates. Colombia is an anomaly in that it has both high unemployment rates and high shares of workers in the informal sector.

Figure 3 shows the high shares of workers employed in the informal sector in Latin America. In contrast to other middle-income and high middle-income countries in other regions, informality is a key feature of labor markets in Latin America. Informal workers encompass all workers hired by employers that do not comply with labor legislation. This includes employers who do not use written contracts or those who may use written contracts but do not receive mandatory minimum wages or benefits according to labor legislation in the country. This often includes those hired by

\footnotetext{
${ }^{3}$ Note that the unemployment rate is measured using household surveys and the definition of unemployment is uniform across countries. However, the lower unemployment rate in these set of countries probably reflects the fact that many are likely to be employed in the informal sector in Central and South America, as discussed below. The equivalent of under-employment in the U.S. and Canada are workers who are part-timers for economic reasons and would like to be employed full-time but can only find part-time employment. In addition, the phenomena of the rise of contingent workers in the U.S. who are not protected by labor regulations would also be similar to informal workers in developing workers.
} 
entities or quasi-Corporations without formal accounts; those hired by family businesses; domestic workers, and the self-employed. Moreover, in recent years, informal workers have grown to include workers employed by formal sector employers through intermediaries or ad-hoc arrangements that do not comply with labor legislation.

Figure 4 shows that informality, like unemployment, varies widely in Latin America. The average share of women in the informal sector in LAC is 55.8\% while the share of men in the informal sector is $51.2 \%$. Honduras has the highest shares of informal workers with $78.5 \%$ women working in the informal sector and $73 \%$ of all men working in the informal sector. However, other countries, including Bolivia, Peru, Paraguay and Nicaragua follow closely with shares above $60 \%$. Even Brazil, which is the country with the lowest shares of informal workers, has female and male shares of informality of $40.3 \%$ and $39.2 \%$, respectively. Thus, in most countries in Latin America, close to half of those employed work in the informal sector, where they are not protected by labor market legislation. In fact, one of the reasons for operating in the shadow economy may be due to efforts by employers to avoid the costs associated with labor market regulations. Unfortunately, operating in the informal economy also means that employers may have lower productivity, precisely because of the avoidance of regulations. In addition, to avoiding the costs of being caught due to enforcement efforts, informal firms tend to remain small and they cannot take advantage of economies of scale, which would make them more productive.

In fact, Figure 5 shows that labor productivity is substantially lower in all Latin American countries and Mexico compared to the U.S. and Canada. Figure 6 shows output per worker measured as GDP in 2011 constant U.S. dollars adjusting for purchasing power parity (PPP). Since labor productivity is measured as output divided by total number of workers, labor productivity declines as employment increases. However, labor productivity depends on many other factors including the quality and skills of workers; the amount and quality of capital used in production, and the production processes used (including the scale of operations). Productivity is typically lower in the informal sector since this sector employs less skilled workers, is less capital-intensive and produces at a smaller scale (see, Levy, 2008). Thus, given the high shares of informal employment in LAC, it is not surprising that labor productivity is many magnitudes lower in all countries in the region. Even Chile's productivity, which has the highest labor productivity in the region, is only $40 \%$ of productivity in the U.S. and $54 \%$ of that in Canada. The average productivity in the Latin American region is only $24 \%$ and $32 \%$ of labor productivity in the U.S. and Canada, respectively. The countries with the lowest labor productivity are Central American Countries, which have large shares of informality, where productivity is only around $10 \%$ of labor productivity in the U.S. and Canada.

Latin American countries have also had high levels of wealth and income inequality even going back to the post-colonial period. ${ }^{4}$ As shown in Figure 7, in the past two decades, however, inequality has fallen substantially in most Latin American countries. While inequality remained almost unchanged from 1995 to 2002, since 2002 inequality fell in all of Latin America. The Gini fell by 0.4 from 2002 to 2008 and by an additional 0.27 since 2008. Between 2002 and 2008, there were drastic reductions in inequality in all countries except for a couple of countries. The Gini fell from 0.56 in 1996 to 0.52 in 2002 and to 0.49 in 2016 (IDB, 2016). Figure 8 shows data from

\footnotetext{
${ }^{4}$ See Williamson (2005) for an economic historian's perspective on the colonial origins of inequality in Latin America.
} 
Messina and Silva (2018) of changes in labor income Gini coefficients for South American and Central American countries. This figure shows declines in the labor income Gini in all countries, except for no change in Honduras and an increase of 0.03 in Costa Rica. Some of these improvements are likely associated with labor market legislation such as increases in the minimum wages in the region. As discussed, in the next section, while labor market legislation may have unintended effects on employment and informality, they can also have positive impacts in terms of protecting those at the lower end of the distribution.

\section{IMPACTS OF LABOR MARKET REgUlations IN LATIN AMERICA}

Some labor market institutions are seen as a way to protect workers against potential unfair treatment by employers. For example, employment protection legislation is introduced with the intention of protecting workers against unfair dismissals. Minimum wages are introduced with the intention of ensuring that workers are paid a'living'wage. Yet, other labor market institutions are introduced with the intention of protecting workers in other ways. For instance, payroll taxes are often used to pay for health insurance, pensions and workers' compensation for those injured on the job. Moreover, unemployment insurance is provided to provide income support for those who loose their jobs.

However, another motivation for labor market institutions is to solve labor market imperfections and improve labor market efficiencies. For example, some have argued that EPL can create a commitment device and solve under-investments in on-the-job training (see, Wasmer, 2006). Others argue that while UI may prolong job searches, it can also help to resolve mismatches in the labor market by prolonging searches and improve the quality of worker-employer matches.

Moreover, others argue that LMI's are well meaning but often have negative unintended consequences. According to these arguments, while many labor market institutions are meant to help workers they can end up hurting workers themselves. The arguments is that most of these LMI's (EPL, MW, payroll taxes, and collective bargaining) is that they increase costs for employers and reduce demand for workers who are subject to these costs, i.e., it reduces demand for formal employment. This means that these regulations may increase unemployment but also increase informal employment.

In this section, I examine each of these labor market institutions and explain the potential benefits and costs. Then, I present evidence based on micro-data on the effects of EPL, MW, payroll taxes, UI and collective bargaining on wages, productivity and unemployment/employment.

\section{A. Employment Protection Legislation}

Figure 9 shows the Employment Protection Legislation index from the ILO in Latin America, the OECD and the U.S. The EPL index in most Latin American countries is higher than that in the U.S., except for the EPL index in Guatemala. In most LAC countries, the EPL index for regular contracts are close to the average EPL index in OECD countries (2.28). The index is even higher than the OECD average in Venezuela, Argentina, Mexico, Honduras, and Colombia. This implies many restrictions on dismissing regular or permanent workers in Latin America, given that OECD 
countries are known to impose high costs to firing workers. The costs of dismissing temporary workers are also much higher for Latin American workers compared to the U.S. and Canada and even compared to the OECD.

Figure 10 shows EPL indices in the OECD, Canada and the U.S. and a number of LAC countries for 2008 and 2014. This figure shows that the OECD EPL index increased for temporary contracts from 2.06 to 2.08 but declined for permanent contracts from 2.36 and 2.28 during this time period. In Latin America, the EPL index also declined sharply in Mexico for both regular contracts (from 2.71 to 2.62) and temporary contracts (from 4.08 to 2.29). By contrast, the EPL index for regular contracts increased in Brazil during this time period from 1.25 to 1.75. In other countries, it stayed the same.

EPL protects those who are employed in the formal sector by requiring employers to pay workers who are dismissed without cause. Thus, stricter EPL should provide a safety net to those who are formally employed. EPL can also help to solve labor market imperfections and overcome underinvestments in on-the-job (OJT) training. EPL can essentially create a commitment device to retain workers and encourage investments in OJT training (Wasmer, 2006).

However, EPL imposes costs for employers not only at the time of dismissal, thus reducing dismissals, but it also increase the expected cost of hiring and reduces new hires. Overall, thus, EPL should reduce turnover by reducing both dismissals and hires. The overall theoretical impact on employment is, however, ambiguous, as fewer workers are fired but also fewer are hired, so the overall effect on employment will depend on which effect dominates. Likewise, the effect on productivity is ambiguous. On the one hand, greater investments in OJT should increase productivity and employers will only hire the very best, thus, increasing productivity. On the other hand, employers facing higher EPL are forced to keep less productive workers and this would decrease productivity.

A number of studies using microdata from household and employer surveys examine accessions and separations from jobs following earlier changes in EPL in Latin America. These studies find increased turnover after EPL becomes less strict. The studies by Kugler $(1999,2004)$ show that, after the severance payments for unjust dismissals fell in Colombia in 1991, both the likelihood of transitioning from unemployment to employment and from employment to unemployment increased. Saavedra and Torero (2004) and Paes de Barros and Corseuil (2004) examine the likelihood of separations after the reductions in the strictness of EPL in Peru and Brazil and they also find evidence of increased turnover. Micco and Pages (2007), instead, use data from all of Latin America as well as data from other countries and examine how more volatile sectors react to different levels of strictness of EPL. They find evidence that stricter EPL reduces turnover in sectors that would be more volatile in a country like the U.S. where costs of dismissals are low. Autor, Kerr and Kugler (2007) study the effects of wrongful discharge laws in the U.S. using establishment level data and find reduced employment adjustments and firm entry after wrongful discharge laws became stricter in many states across the U.S in the 1980s and 1990s.

As mentioned above, the effects of EPL on employment are theoretically ambiguous. Kugler (2004) uses a model and the findings on increased hiring and dismissals after EPL declined and she finds evidence of increased employment in Colombia. This would be consistent with decreased 
employment as EPL becomes stricter. Consistent with this evidence, Besley and Burgess (2004) find similar evidence for India, where pro-worker labor market reforms reduced employment. Ahmed and Pages (2009) also find that stricter EPL reduces employment. By contrast, Micco and Pages (2007) find no evidence of stricter EPL having any effect on average employment per plant. Other evidence based on micro-data for other countries with similar levels of income also shows no impact of EPL strictness on employment. Avdagic (2015) examines data for Central Europe and finds no effects of EPL on overall youth employment, once controls for other labor market legislation are included. Autor, Kerr and Kugler (2007) find evidence of increased employment after the increased strictness of wrongful discharge laws in the U.S. Thus, the evidence on the impact of EPL on employment is mixed.

Like the impact on employment, the theoretical impact of EPL on productivity is ambiguous. Stricter EPL can increase OJT and productivity. In addition, stricter EPL can induce employers to keep unproductive workers, who they can only dismiss at a high cost. Also, EPL makes employers more selective and hire more productive workers. There are only a handful of studies looking at the impact of EPL on productivity. Eslava et al. (2009) find that EPL has small negative effects on productivity in Colombia. The study by Micco and Pages (2009), which include data for LAC, finds a decline in value added in sectors most affected by EPL. The only other evidence of EPL on productivity for a high middle-income country comes from India. Besley and Burgess (2004) and Ahsad and Pages (2009) find that EPL reduces productivity in India. Similarly, Autor, Kerr and Kugler (2007) find small negative effects of stricter wrongful discharge laws in the U.S. over the 1980s and 1990s on productivity.

Thus, the evidence on the impacts of EPL on turnover is clear-cut - the effects are large and negative. The evidence on the impacts of productivity show consistent negative but small effects. By contrast, the empirical impacts of EPL on employment are ambiguous. Thus, one cannot rule out that EPL can sometimes increase employment.

\section{B. Minimum Wages}

Figures 11 and 12 show the ratios of the minimum wage to the mean and median wages in Latin American countries and in the U.S. for comparison. These ratios show whether the minimum wage (MW) is likely to be binding in each of these countries. Figure 11 shows that the ratio of the minimum wage to mean wage varies widely. Honduras and Guatemala have very high ratios of 0.99 and 0.97, which means that the minimum wage is at 99 and 97 percent of the mean wage in these countries. By contrast, the MW seems not to be highly binding in Mexico and Peru, where the MW is 0.29 and 0.16 . That means that the MW is only $30 \%$ and $16 \%$ of the mean wages in Mexico and Peru. The average ratio for all of LAC is 0.6 , so that the MW is likely to be binding in most countries in the region. Figure 12 shows the ratios of the MW to median wages, which is probably a better measure of the extent to which the MW affects people in the labor market. In LAC, where inequality is so very high, the mean could be inflated by outliers at the top of the earnings distribution in economies where inequality is very high. On the other hand, very low earnings at the bottom of the distribution in economies with large informal sectors can substantially push down average wages. The overall ratio of the MW to the median wage is higher than the ratio of the MW to the average wage, 0.67 vs. 0.6. Moreover, when looking at specific countries, most ratios go up when comparing to the median wage (Argentina0.87 vs. 0.68, Panama 0.72 vs. 0.57, 
Venezuela 0.72 vs. 0.67 , Brazil 0.7 vs. 0.43 , Peru 0.61 vs. 0.16 , Uruguay 0.45 vs. 0.39 , Mexico 0.34 vs. 0.29 ). Thus, given that there are so many informal sector workers, comparing the MW to the median wage may be a better way to gauge how binding the minimum wage is in Latin America. All in all, the MW does appear to be above the wage of a large fraction of workers in most Latin American countries.

Minimum wages set a floor that must be paid to formal sector workers. The main rationale behind setting MW is to increase earnings and living conditions for workers. However, if the MW is very low, then they will not be effective in this regard and will not be binding. In addition, MW can address the inefficiently low employment generated when an employer has monopsony power introducing a labor market imperfection. In this case, setting a MW will improve efficiency by increasing employment. Finally, MW can act as an efficiency wage and overcome market failures related to information asymmetries through moral hazard and adverse selection. That is, in cases when employers do not observe the actual quality of workers or the effort they put, offering higher wages, known as efficiency wages, will increase productivity. In this case too, MW will increase employment closer to the optimal level (see, e.g., Shapiro and Stiglitz, 1984, and Akerlof and Yellen, 1986).

MW can have a direct impact on wages by increasing the wage of those earning below the legal minimum. In addition, the MW can have indirect effects on wages. Establishing a legal MW can have a positive effect on wages for formal sector workers earnings above the minimum. This effect known as the "numeraire effect"causes wages above the minimum wage to increase at multiples of the minimum wage, simply because employers and employees may use the MW as a reference of how much more above a 'living'wage someone is. In addition, the legal minimum could potentially increase the wages for informal workers earning below the minimum, even if they are not covered by the legislation. This is known as the "lighthouse effect", simply because even those in the informal sector may be inclined to pay more as the MW increases signaling that the 'living' wage has risen.

Two studies for Latin America show positive effects on wages. Maloney and Nunez (2004) and Kristensen and Cunningham (2006) find large positive effects for those between 0.7-0.9 of the MW. In addition, they show evidence of both 'lighthouse' and 'numeraire' effects. These studies use graphical analysis and find positive impacts on the self-employed as well as on those higher up in the distribution, with spikes at multiples of the MW. There is also similar evidence of positive impacts on wages using micro-data for other high middle-income countries, including for South Africa (Dinkelman and Ranchod, 2011; Bhorat, 2013), Thailand (Lathapipat and Poggi, 2016), Turkey (Papps, 2012) and China (Fang and Ling, 2013; Lin and Yun, 2016).

An indirect and unintended effect of minimum wages is that they can reduce employment if employers' costs increase. On the other hand, minimum wages can increase employment if there is a monopsony market or information asymmetries. Finally, it is possible that there is no effect on employment if workers become more productive as a result of higher wages or if the higher wages are passed on to consumers as higher prices.

The evidence using micro-data shows mixed evidence. Maloney and Nunez (2004) use micro-data from Colombia find that an increase in the MW of $9 \%$ in 1999 reduces the probability of becoming 
unemployed by $1.4 \%$. However, the 1999 increase in the MW in Colombia coincides with an economic downturn which likely accounts for the rise in unemployment. Other papers for other high middle-income countries, which instead rely within country variation, show either no impact or small negative impacts on employment. Dinkelman and Ranchod (2011) and Bhorat et al. (2003) find no impact on employment in South Africa and Papps (2012) finds no effect on employment in Turkey. Lathapipat and Poggi (2016), Rama (2001), del Carpio et al. (2015) find small negative effects in Indonesia. For example, del Carpio et al. (2015), which uses firm level data and controls for firm fixed effects and various employer and employee characteristics finds that a $10 \%$ increase in the MW in Indonesia reduces employment by $0.34 \%$. Similarly, Lathapipat and Poggi (2016) and del Carpio, Messina and Sanz-de-Galeano (2018) find small negative effects on employment in Thailand. Del Carpio, Messina and Sanz-de-Galeano (2018) use a credible difference-in-difference estimation strategy using variation in how binding the MW is across provinces and find that the effects of the MW are small. For the U.S., a good meta-study finds that most results on the impact of the MW on employment hover around zero (see Wolfson and Belman, 2016).

Thus, while MWs clearly increase wages along the distribution and reduce inequality, the evidence on employment tends to show small or no effects.

\section{Payroll Taxes}

Employers and employees pay payroll taxes as a share of employees' wages and use them to finance a number of services for workers. In most countries, these are often used to pay for health insurance and pensions, and in some cases for training, childcare and workers' compensation. These taxes are mandatory for formal sector employers. Figure 13 shows payroll tax rates in Latin American countries as well as Canada, as well as the OECD average. Canada and the OECD countries have high rates - the payroll tax rate is $65 \%$ in Canada and the average tax rate in the OECD is $41 \%$. The average in LAC is $25 \%$. However, payroll tax rates vary widely in the region. The payroll tax rate is $91 \%$ in Brazil, $48 \%$ in Argentina, 39\% in Mexico, 32\% in Costa Rica and $31 \%$ in Colombia and $26 \%$ in Paraguay, all countries with an average rate above the mean in the region. By contrast payroll tax rates are very low in all of Central America $-13 \%$ in Honduras, $15 \%$ in the Dominican Republic, $17 \%$ in Guatemala and $17 \%$ in El Salvador.

Payroll taxes can provide valuable services to workers. In some cases, these are valuable in overcoming market failures and providing insurance that would not be provided by the market. Payroll taxes can, however, add to labor costs for employers and they can reduce demand for formal employment and increase informality. However, if workers fully value the services funded with the payroll taxes, then they would be willing to pay for these as lower wages and the cost would be passed on to workers. In this case, there would be no effect on formal employment. Full pass-through will not occur, though, either if the services are not fully valued or if there are restrictions on how low a wage can be paid (e.g., if there are binding minimum wages).

Evidence for Latin America largely shows partial pass-through and negative impacts on formal employment. Heckman and Pages (2004) examine the impact of social security contribution in an unbalanced panel of countries and find $36 \%$ pass-through and $4.5 \%$ reduction in employment in 
Latin America. Kugler and Kugler (2011) examine the increase in payroll taxes in Colombia following the 1994 reform. They use a panel of Colombian manufacturing plants and they find that a $10 \%$ increase in payroll taxes lowered formal wages by between $1.4 \%$ and $2.3 \%$ (i.e., a passthrough of between $14 \%$ and $23 \%$ ) and reduced formal employment between $4 \%$ and $5 \%$, in line with the Heckman and Pages (2004) results. Kugler, Kugler and Herrera (2017) examine the recent 2013 reform, which reduced payroll taxes for workers earnings less than $10 \mathrm{MW}$ and for selfemployed workers hiring more than 3 employees. This study uses a difference-in-difference strategy together with three different sources of data (household surveys, social security records and the monthly manufacturing surveys) to examine the impact of this reform. We find that formal employment increases with all three sources of data. By contrast, Cruces et al. (2010) use administrative data for Argentina and find a 55\% shifting to wages but no effect on employment. However, this partial pass-through is not consistent with no disemployment at all. Gruber (2001) find full pass-through and no effect on employment in the case of a tax reduction for pensions in Chile.

Also, since payroll taxes can push employers away from hiring formal workers and towards informality, they can generate misallocation in the economy towards smaller and less capitalintensive firms that are also less productive. Thus, reductions in payroll taxes in the region during the past few decades should also contribute towards increases in productivity. Levy (2008) discusses the adverse effects of payroll taxes on firm size and capital investments and, in turn, on productivity and Eslava et al. (2009) show the misallocation effects and reductions in productivity due to stricter labor market regulations in Colombia.

\section{Unemployment Insurance}

Unemployment insurance is often paid to uninsured workers who have been laid off without cause. While UI is available in most OECD countries, it is only available in a handful of Latin American countries. Only Venezuela, Uruguay, Chile, Argentina and Brazil have unemployment insurance. Moreover, UI benefits offered in these countries are not very generous. The gross replacement rate, which gives the fraction of the earnings in the previous job replaced by UI, is only $30 \%$ in Venezuela, 25\% in Uruguay, 23\% in Chile 22\% in Argentina and 15\% in Brazil. This contrasts with a $57 \%$ replacement rate in the U.S. and $59 \%$ in Canada.

Unemployment insurance helps those who already lost their jobs keep a source of income and stay out of poverty. Insurance can also overcome market imperfections when there are frictions in matching. UI allows workers to search longer for a job that is more suitable to their skill level (Farooq and Kugler, 2017). Thus, one would expect longer unemployment spells but also higher post-unemployment wages and productivity. However, UI can have unintended negative consequences. UI can prolong unemployment spells without improving post-unemployment matches if UI increases reservation wages or if workers search less during unemployment due to moral hazard.

Evidence for Latin America shows mainly lengthened spells of unemployment, but only one study shows positive impact on wages. The study by Gonzales-Rozada and Ruffo (2016) for Argentina examines the 2006 reform which expanded eligibility for UI. The study shows that UI lengthened unemployment spells and had a positive impact on post-unemployment wages. A study by 
Cunningham (2000) for Brazil shows that UI prolongs job search and increases self-employment and entrepreneurship but has no effect on wages. By contract, the study by Huneeus (2012) for Chile shows no effect on employment or wages.

Evidence for other high middle-income countries in Central Europe show largely prolonged unemployment spells in Hungary, Bulgaria, and Poland (Micklewright and Nagy, 1998; Kotzeva, 1996; Steiner and Kwisikowski, 1995; Adamchik, 1999). By contrast, evidence for Romania shows higher likelihood of leaving unemployment for those receiving UI (Earle and Pauna, 1998). Moreover, evidence for Hungary and Poland show that UI reduces poverty by $4.1 \%$ and $3.2 \%$, respectively (Vodopivec et al., 2003).

Overall, the evidence for Latin America and Central Europe shows that more generous UI prolongs unemployment spells and has either a positive effect or no effect on wages.

\section{E. Unionization and Collective Bargaining}

Unionization has not been widespread in most of Latin America. Only the countries in the Southern cone have had a tradition of strong unions. Unions protect workers by raising wages and establishing working conditions for workers, by organizing workers and collecting fees from members. Union members, in turn, are protected by the conditions negotiated by unions with employers. However, other workers may also be protected by union conditions depending on the level of collective bargaining coverage. Collective bargaining can cover workers at the establishment level, sector level or country level. Thus, the share of workers covered by collective bargaining will generally not coincide with the share of workers who are union members.

Figure 15 shows the trade union density in most Latin American countries. In Bolivia, 39.1\% of workers are unionized, which is the highest share of unionization in the whole region. Uruguay has the second highest rate of unionization at $30.1 \%$. These are the only two countries with unionization rates above Canada's rate of $28.4 \%$. The average rate of unionization across the region is, however, much lower at $16.3 \%$, but still higher that the U.S. rate of $10.3 \%$. A handful of countries in the Southern Cone (Argentina, Chile and Brazil) and Costa Rica and El Salvador have unionization rates above the mean. By contrast, Andean countries and Central American countries tend to have much lower unionization rates close to the $10 \%$ in the U.S. or lower. These low unionization rates, alone, would suggest a limited role for unions in most of the region role.

Figure 16, however, shows that a much higher share of workers is protected by the conditions negotiated by unions in the region. Collective bargaining coverage reaches almost national coverage in Uruguay (94.6\%), Cuba (81.4\%) and Brazil (70.5\%). Argentina also covers half of its workforce through collective bargaining arrangements. These coverage rates are much higher than the unionization rates of around 30\% in Uruguay and Argentina and 20\% in Brazil. By contrast, collective bargaining coverage and unionization rates are almost at par in Canada $(28.4 \%$ vs. $30.3 \%)$ and the U.S. (10.3\% vs. $11.5 \%)$. The closer coverage and unionization rates in Canada and the U.S. are due to the fact that collective bargaining takes place at the establishment level in these countries. By contrast, the level of collective bargaining in most of Latin America is at the sectorial or even national level, which means that the average collective bargaining coverage in LAC is around $24.8 \%$ compared to the unionization rate of $16.3 \%$. Yet, on average only about a 
quarter of all workers in the region are covered by collective bargaining agreements, and the median collective bargaining coverage is only a tenth of all workers.

Unions can have various effects on the labor market. First, unions typically raise wages and compress wage differentials for unionized workers. However, in Latin America, where unionized workers tend to be more educated, unionization is likely y to increase overall wage inequality in the region (Kuhn and Marquez, 2005). Second, it has been argued that by offering "voice" to workers, unions can improve worker morale and productivity (Freeman and Meddoff, 1984). However, given that unions increase wages and establish limits on working conditions, unions may end up increasing costs for employers and reducing employment.

Evidence for Latin America based on micro-data shows evidence of unions on wages, productivity, and employment. Cassoni et al. (2005) examine the impact of unions in Uruguay, where negotiations have moved from a centralized system toward enterprise-level bargaining. They use data from a panel of establishments from 1988 to 1995. The evidence shows positive impacts on wages and greater investments, but a reduction in profits and no effect on employment. This would indicate that the movement towards less union coverage has had a positive impact wages and investments, though not on employment.

Menezes-Fihlo et al. (2005) examine data from Brazilian manufacturing firms from 1988 and 1998. They find that union density has an inverted U-shape effect on employment and productivity. At the current level of union density in Brazil the effects are positive on both employment and productivity. However, they also find that there are negative impacts on profitability. By contrast, Saavedra and Torero (2005) use a panel of manufacturing firms in Peru from 1994 and 1996 and find that unions reduce profits, but have no effect on productivity.

Thus, overall the results show negative effects on profits. However, the results on the effects of unions on productivity and employment in Latin America are mixed. There are no effects on employment in Uruguay but positive effects in Brazil (with an inverted U-shape). Also, there are no effect on productivity in Peru but a positive effect in Brazil (with an inverted U-shape). Thus, the effects of unions overall appear to be positive if unionization is moderate in Latin American countries, but nil or negative if unionization rates are very low or very high.

\section{IMPACTS OF DEMOGRAPHIC FACTORS}

\section{A. Skill: Education and Age}

Since the 1980s the number of more educated workers has been rising steadily in Latin America. According to Messina and Silva (2017), the average years of education for adults increased between 1990 and 2010 from 5.8 to 8.3. Likewise, they find that the fraction of high school graduates risen from $21 \%$ to $36 \%$ during this period in the region. Ferreira et al. (2016) also report that while the share of individuals with a primary education has declined from $54 \%$ to $39 \%$ between 1990 and 2010, the share of college-educated has doubled during this time period. Figure 17 shows the average years of schooling across different countries. While the years of schooling have increased substantially, the average years of schooling in Latin America remains low. While 
the average years of schooling in the U.S. overall is 11 years, it is only 5 years on average in Latin America. Messina and Silva (2017) also report that experience as measured by age has been increasing. The Latin American population has been aging, increasing the share of older workers relative to younger workers.

Since more educated and older workers are more skilled, the secular growth in the share of more educated and older workers should increase productivity. Also, more educated and older workers are more likely to be employed and, in particular, to be employed in the formal sector of the economy. These trends, then, are likely to have contributed to the decline in informality and unemployment during this time period.

However, the effects of the increase in the supply of more educated and older workers could have either a positive or a negative impact on inequality. On the one hand, given no change in demand, the rise in the supply of more educated and older workers would reduce the returns to skill and reduce inequality. On the other hand, within group inequality is greater for more educated and older workers, so the increase in these groups of workers could mechanically increase inequality.

Returns to skill have indeed fallen during this period. According to Messina and Silva (2017), since the 2000s, the earnings of unskilled workers have grown faster than the earnings of the skilled. According to Rodriguez-Castellan et al. (2016), the earnings for those at the lower tail of the distribution rose by $50 \%$ since 2002 , and by $32 \%$ for those in the middle of the distribution and by $15 \%$ for those at the upper tail of the distribution. This study also finds that since 2003, the gap between the college-educated and those with primary schooling fell from $330 \%$ to $240 \%$. Figure 18 shows the changes in the returns to skill between 1995 and 2013 in different countries from Messina and Silva (2017). The figure shows that the return to skill has declined in all countries in the region with the exception of Costa Rica and the Dominican Republic.

Likewise, the experience premium has been declining in Latin America since the early 2000s. According to Messina and Silva (2017), the experience premium between for those with 21-30 years of experience relative to those with 0-5 years of experience has declined from $56 \%$ in 1993 to $33 \%$ in 2013.

Lopez-Calva and Lustig (2010) find that $50 \%$ of the decline in earnings inequality can be explained by the narrowing in earnings for skilled relative to the unskilled. Thus, the fall in the returns to skill has dominated the mechanical effect of having more educated and older workers on inequality. In fact, the Gini fell by close to 15 in Brazil and by 7 in Argentina, Mexico, Chile and Bolivia and by close to 5 in Nicaragua, Panama, Honduras and El Salvador. Only Peru, Uruguay and Ecuador had reductions in inequality of less than 5 in their Gini coefficients.

\section{B. Gender}

The labor participation of women has grown during the past two decades. This can potentially reduce employment and increase informality since women are more likely to be unemployed and to work in the informal sector. The increased supply of women could mechanically increase inequality since women typically earn less than men. Figure 19 shows that the gender gap is positive in most countries. The gender gap is $20 \%$ in Chile and Peru and $15 \%$ in Brazil. It is 
between 5\% and 10\% in Uruguay, Dominican Republic, Mexico, Venezuela and Bolivia. It is positive but below 5\% in Panama, Nicaragua, Guatemala and Colombia. By contrast, women earn on average more than men in El Salvador, Costa Rica, Argentina, Ecuador and Paraguay.

The entry of women into the labor force could, however, contribute to an increase in the gender gap itself if women are locked into certain occupations, but to a decline if women compete for jobs with men in the same sectors. According to Messina and Silva (2017) the gender gap was stable during the period from 1993 to 1999. The gender gap then had a large decline between 1999 and 2003 and a smaller decline starting since 2003. Thus, the entry of women into the labor force has contributed to the decline in inequality.

\section{Conclusion}

The performance of the Latin American labor market has improved along several dimensions in the past few decades. Unemployment and informality have declined over the past decades and inequality has also decreased substantially. Nonetheless, unemployment, informality and inequality all continue to be higher in Latin America than in the rest of the world. Moreover, productivity has remained roughly constant throughout the past few decades and productivity remains lower in LAC compared to the U.S. and Canada.

Improvements in terms of the level and quality of employment over the past decades are likely related to demographic factors such as the growth in more educated and older workers. However, institutional factors that affect the demand for labor are also likely to have contributed to these declines in unemployment and informality. The reduced strictness in EPL and payroll taxes is likely to have boosted formal employment. Finally, centralized collective bargaining in a number of countries could have contributed to higher formal employment in countries with medium unionization rates in the region, although they may create insider-outsider problems for workers who are not able to get their foot in the door of formal firms. On the other hand, however, higher minimum wages probably had little effect or a small effect in terms of reducing formal employment.

Demographic factors including the increase in skilled workers and women in the labor force have also contributed to the decline in inequality in the region over the past two decades. Moreover, a number of institutional factors consistently weigh towards higher wages and decreased inequality. Higher minimum wages and more generous unemployment insurance increase earnings for those at the lower end of the distribution and reduce inequality, insofar as they do not lower employment creation as the evidence seems to suggest. Unionization in Latin America, however, is more likely to increase wages for those higher up in the income distribution, thus not necessarily contributing to reduce inequality. On the other hand, the imposition of payroll taxes should reduce wages for formal sector. However, since payroll taxes have been declining in the region, these institutional changes have, if anything, likely contributed to lower inequality if the less skilled benefit more from these wage increases that result from lower payroll taxes.

In terms of productivity, the evidence on how various institutions and demographic factors affect productivity is more scant. The evidence reviewed suggests that unions increase productivity for those who get unionized jobs. However, the evidence on Employment Protection Legislation 
indicates that EPL decreases productivity in the region. Unfortunately, there is no evidence on the impact of MW and UI on productivity in the region, but evidence from other regions points to positive impacts of these institutional factors on productivity. Yet, payroll taxes or other factors that push employers away from hiring formal workers and towards informality generate misallocation in the economy towards smaller and less capital-intensive firms that are also less productive. Thus, reductions in payroll taxes in the region during the past few decades should also contribute towards increases in productivity (Eslava et al., 2009). 


\section{REFERENCES}

Adamchik, Adam. 1999. "The Effect of Unemployment Benefits on the Probability of Reemployment in Poland," Oxford Bulletin of Economics and Statistics, 61(1): 95-108.

Ahmed, Ahsad, and Carmen Pages. 2009. "Are All Labor Regulations Equal? Evidence from Indian Manufacturing," Journal of Comparative Economics, 37(1): 62-75.

VI.

Akerlof, George and Janet Yellen. 1986. Equilibrium Wage Models of the Labor Market. Cambridge: Cambridge University Press.

Almeida, Rita and Pedro Carneiro. 2009. "Enforcement of Labor Regulation and Informality," American Economic Review: Applied Economics, 4(3): 64-89.

"Inequality and Employment in a Dual Economy: Enforcement of Labor Regulation in Brazil," IZA Working Paper No. 3094.

Almeida, Rita and Pedro Carneiro. 2006. "Enforcement of Regulation, Informal Labor and Firm Performance," Mimeo.

Autor, David, William Kerr and Adriana Kugler. 2007. "Do Employment Protections Reduce Productivity? Evidence from U.S. States,” Economic Journal, June (2007), 117: F189-F217.

Avdagic, Sabina. 2015. "Does Deregulation Work? Reassessing the Unemployment Effects of Employment Protection," British Journal of Industrial Relations, https://doi.org/10.1111/bjir.12086.

Besley, Timothy and Robin Burgess. 2004. "Can Labor Regulation Hinder Economic Performance? Evidence from India," Quarterly Journal of Economics, 119(1): 91-134.

Betcherman, Gordon, Meltem Daysal and Carmen Pages. 2009. "Do Employment Subsidies Work? Evidence from Regionally Targeted Subsidies in Turkey?" Labour Economics, 17: 710722.

Bhorat, Haroon Ravi Kanbur and Natasha Mayer. 2013. "The Impact of Sectoral Minimum Wage Laws on Employment, Wages, and Hours of Work in South Africa," IZA Journal of Labor and Development, 2(1), https://link.springer.com/article/10.1186/2193-9020-2-1.

Camacho, A., J. Messina, and J. Uribe. 2016. "The Expansion of Higher Education in Colombia: Bad Students or Bad Programs?" Background paper for Wage Inequality in Latin America: Understanding the Past to Prepare for the Future. Washington, D.C.: World Bank. http://www.jsmessina.com/assets/papers/CMU.pdf.

Campos-Vázquez, R. M., L.-F. López-Calva, and N. Lustig. 2015. "Declining Wages for CollegeEducated Workers in Mexico: Are Younger or Older Cohorts Hurt the Most?" Policy Research 
Working Paper 7546, Washington, D.C.: World Bank.

Cassoni, Adriana, Gaston Labadie and Gabriela Fachola. 2005. "The Economic Effect of Unions in Latin America: Their Impact on Wages and the Economic Performance of Firms in Uruguay," in pages 101-142, in Peter Kuhn and Gustavo Márquez, eds., What Difference Do Unions Make? Their Impact on Productivity and Wages in Latin America. Washington, D.C.: Inter-American Development Bank.

Cunningham, Wendy. 2000. "Unemployment Insurance in Brazil: Unemployment Duration, Wages, and Sectoral Choice," Mimeo.

Del Carpio, Ximena, Julian Messina, and Anna Sanz-de-Galeano. 2018. Minimum Wage: Does It Improve Welfare in Thailand?" Review of Income and Wealth.

Del Carpio, Ximena, Ha Nguyen, Laura Pabon and Liang Wang. 2015. "Does the Minimum Wage Affect Employment? Evidence from the Manufacturing Sector in Indonesia," IZA Journal of Labor and Development, 4(17).

Dinkelman, Taryn and Vimal Ranchhod. 2011. "Evidence on the Impact of Minimum Wage Laws in an Informal Sector: Domestic Workers in South Africa," CEPR Working Paper No. 8682. London: Center for Economic Policy Research.

Duryea, Suzanne and Marcos Robles. 2016. Social Pulse in Latin America and the Caribbean 2016: Realities and Perspectives. Washington, D.C.: Inter-American Development Bank.

Earle, John and Catalin Paune. 1998. "Long-term Unemployment, Social Assistance and Labor Market Policies in Romania," Empirical Economics, 23(1-2): 203-235.

Eslava, Marcela, John Haltiwanger, Adriana Kugler and Maurice Kugler. 2010. "Factor Adjustments after Deregulation: Panel Evidence from Colombian Plants," Review of Economics and Statistics, 92(2): 378-391.

Fang, Carl and Carl Lin. 2015. "Minimum Wages and Employment in China," IZA Journal of Labor Policy, 4(1):1-30. https://link.springer.com/article/10.1186/s40173-015-0050-9.

Farooq, Ammar and Adriana Kugler. 2017. "Do Unemployment Insurance Extensions Reduce Skill Mismatches?" Mimeo.

Ferreira, F., S. Firpo, and J. Messina. 2014. "A More Level Playing Field? Explaining the Decline in Earnings Inequality in Brazil, 1995-2012." International Research Initiative on Brazil and Africa (IRIBA) Working Paper 12. United Kingdom: University of Manchester.

Ferreira, M. M., C. Avitabile, J. Botero Alvarez, and S. Urzua. Forthcoming. "At Crossroads: Higher Education in Latin America and the Caribbean", Directions in Development. Washington, D.C.: World Bank. 
Gasparini, L., S. Galiani, G. Cruces, and P. Acosta. 2011. "Educational Upgrading and Returns to Skills in Latin America: Evidence from a Supply-Demand Framework, 1990-2010." Policy Research Working Paper 5921. Washington, D.C.: World Bank.

Freeman, Richard and James Meddoff. 1984. What Do Unions Do? New York: Basic Books. Gonzalez-Rozada, Martin and Hernán Ruffo. 2016. "Optimal Unemployment Benefits in the Presence of Informal Labor Markets,” Labour Economics, 41: 204-227.

Gruber, Jonathan. 1997. "The Incidence of Payroll Taxation: Evidence from Chile," Journal of Labor Economics, 15: S72-S101.

Heckman, James and Carmen Pagés. 2004. "Introduction," in pages 1-108, in James Heckman and Carmen Pages, eds., Law and Employment: Lessons from Latin America and the Caribbean. Chicago: Chicago University Press.

Huneeus, Cristobal, Silvia Leyva and Alejandro Micco. 2012. "Unemployment Insurance and Search Effort in Chile,” IDB Working Paper No. IDB-WP-313.

Jones, Derek and Mariana Kotzeva. 1998. "Work Incentives and Other Effects of the Transition to Social Assistance in the Transition Economies: Evidence from Bulgaria," Empirical Economics, 23(1-2): 237-261.

Kristensen, Nicolai and Wendy Cunningham. 2006. "Do Minimum Wages in Latin America and the Caribbean Matter? Evidence from 19 Countries," World Bank Working Paper No. 3870. Washington, D.C.: World Bank.

Kugler, Adriana. 1999. "The Impact of Firing Costs on Turnover and Unemployment: Evidence from the Colombian Labor Market Reform," International Tax and Public Finance Journal, August, 6(3): 389-410.

Kugler, Adriana. 2004. "The Effects of Job Security Provision Regulations on Labor Market Flexibility: Evidence from the Colombian Labor Market Reform," in pages 183-228, in James Heckman and Carmen Pagés, eds., Law and Employment: Lessons from Latin America and the Caribbean. Chicago: Chicago University Press.

Kugler, Adriana and Maurice Kugler. 2009. "Labor Market Effects of Payroll Taxes in Developing Countries: Evidence from Colombia," Economic Development and Cultural Change, 57: 335-358.

Kugler, Adriana. 2011. "Is There an Anti-Labor Bias of Taxes? A Survey of the Evidence from Latin America and Around the World," IDB Working Paper No. IDB-TN-299, July.

Kugler, Adriana, Maurice Kugler and Luis Omar Herrera. 2017. "Do Payroll Tax Breaks Stimulate Formality: Evidence from Colombia's Reform," Economia, Summer.

Kuhn, Peter and Gustavo Márquez. 2005. "What Difference Do Unions Make? Their Impact on Productivity and Wages in Latin America," in pages 1-12, in Peter Kuhn and Gustavo Márquez, 
eds., What Difference Do Unions Make? Their Impact on Productivity and Wages in Latin America. Washington, D.C.: Inter-American Development Bank.

Lathapipat, Dilaka and Cecilia Poggi. 2016. "From Many to One: Minimum Wage Effects in Thailand," PIER Discussion Paper.

Levy, Santiago. 2008. Good Intentions, Bad Outcomes: Social Policy, Informality and Economic Growth in Mexico. Washington, D.C.: Brookings Institution Press.

López-Calva, Luis, and Nora Lustig. 2010. Declining Inequality in Latin America: A Decade of Progress? Washington, D.C.: Brookings Institution.

Maloney, William and Jairo Nunez. 2004. "Minimum Wages in Latin America," in pages 109130, in James Heckman and Carmen Pagés, eds., Law and Employment: Lessons from Latin America and the Caribbean. Chicago: Chicago University Press.

Manacorda, M., C. Sánchez-Páramo, and N. Schady. 2010. "Changes in Returns to Education in Latin America: The Role of Demand and Supply of Skills," Industrial and Labor Relations Review, 63 (2): 307-26.

Menezes-Filho, Helio Zylberstajn, Jose Paulo Chahad and Elaine Pazello. 2005. "Unions and the economic Performance of Brazilian Establishments," in pages 77-100, in Peter Kuhn and Gustavo Márquez, eds., What Difference Do Unions Make? Their Impact on Productivity and Wages in Latin America. Washington, D.C.: Inter-American Development Bank.

Messina, Julian and Joana Silva. 2017. Wage Inequality in Latin America: Understand the Past to Prepare for the Future. Washington D.C.: World Bank.

Mickleright, John and Gyula Nagy. 1998. "The Implications of Exhausting Unemployment Insurance Entitlement in Hungary," Budapest Working Paper 1998/2. Budapest: Budapest School of Economics.

Mondragon-Velez, Camilo, Ximena Pena and Daniel Wills. 2010. "Labor Market Rigidities and Informality in Colombia," Economia, 11(1): 65-95.

Paes de Barros, Ricardo and Carlos Enrique Corseuil. 2004. "The Impacts of Regulations on Brazilian Labor Market Performance," in pages 273-350, in James Heckman and Carmen Pagés, eds., Law and Employment: Lessons from Latin America and the Caribbean. Chicago: Chicago University Press.

Pagés, Carmen and Alejandro Micco. 2007. "The Economic Effects of Employment Protection: Evidence from International Industry-Level Data," IDB Working Paper No. 1095. Washington: Inter-American Development Bank.

Papps, Kerry. 2012. "The Effects of Social Security Taxes and Minimum Wages on Employment: Evidence from Turkey," Industrial and Labor Relations Review, 65(3). 
Rama, Martin. 2001. "The Consequences of Doubling the Minimum Wage: The Case of Indonesia," Industrial and Labor Relations Review, 54(4): 864-881.

Rodriguez-Castelan, Carlos, Luis Lopez-Calva, Nora Lustig and Daniel Valderrama. 2016. "Understanding Wage Inequality in LAC: a Set of Stylized Facts," Policy Research Working Paper 7795, World Bank, Washington, D.C.

Saavedra, Jaime and Maximo Torero. 2004. "Labor Market Reforms and Their Impact over Formal Labor Demand and Job Market Turnover: The Case of Peru," in pages 131-184, in James Heckman and Carmen Pages, eds., Law and Employment: Lessons from Latin America and the Caribbean. Chicago: Chicago University Press.

Saavedra, Jaime and Maximo Torero. 2005. "Union Density Changes and Union Effects on Firm Performance in Peru," in pages 33-76, in Peter Kuhn and Gustavo Márquez, eds., What Difference Do Unions Make? Their Impact on Productivity and Wages in Latin America. Washington, D.C.: Inter-American Development Bank.

Shapiro, Carl and Joseph Stiglitz. 1984. "Equilibrium Unemployment as a Worker Discipline Device,” American Economic Review, 74(3): 433-444.

Steiner, Viktor, and Eugeneiusz Kwiatkowski. 1995. "The Polish Labour Market in Transition," ZEW Discussion Paper No. 95-Q3.

Urizar, Carmen and Sigfrido Lee. 2005. "The Effect of Unions on Productivity: Evidence from Large Coffee Producers in Guatemala," in pages 143-172, in Peter Kuhn and Gustavo Márquez, eds., What Difference Do Unions Make? Their Impact on Productivity and Wages in Latin America. Washington, D.C.: Inter-American Development Bank.

Vodopivec, Milan, Andreas Worgotter, and Dhushyanth Raju. 2003. "Unemployment Benefit Systems in Central and Eastern Europe: a Review of the 1990s," Social Protection and Labor Policy and Technical Notes 26307.

Wasmer, Etienne. 2006."General versus Specific Skills in Labor Markets with Search Frictions and Firing Costs," American Economic Review, 96(3): 811-831.

Williamson, Jeffrey G. 2015. "Latin American Inequality: Colonial Origins, Commodity Booms, or a Missed 20th Century Leveling?" NBER Working Paper 20915. Cambridge, MA: NBER.

Wolfson, Paul and Dale Belman. 2016. "15 Years of Research on U.S. Employment and the Minimum Wage,” Tuck School of Business Working paper No. 2705499. 
Figure 1: Unemployment Rate Latin America \& the Caribbean

14

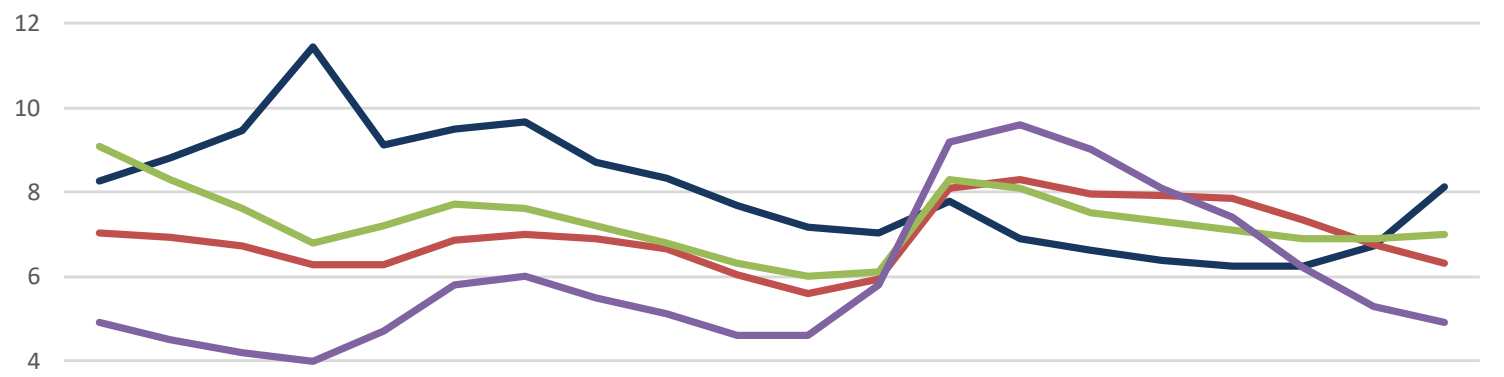

2

19971998199920002001200220032004200520062007200820092010201120122013201420152016

Latin America \& the Caribbean $\quad$ OECD Canada United States

Notes: Unemployment rate, total as a percentage of the labor force (national estimates) from 1997 to 2016. Data provided by the World Bank Databank available at

$<$ http://databank.worldbank.org/data/reports.aspx?source=2\&series=SL.UEM.TOTL.NE.ZS\&country=\#>

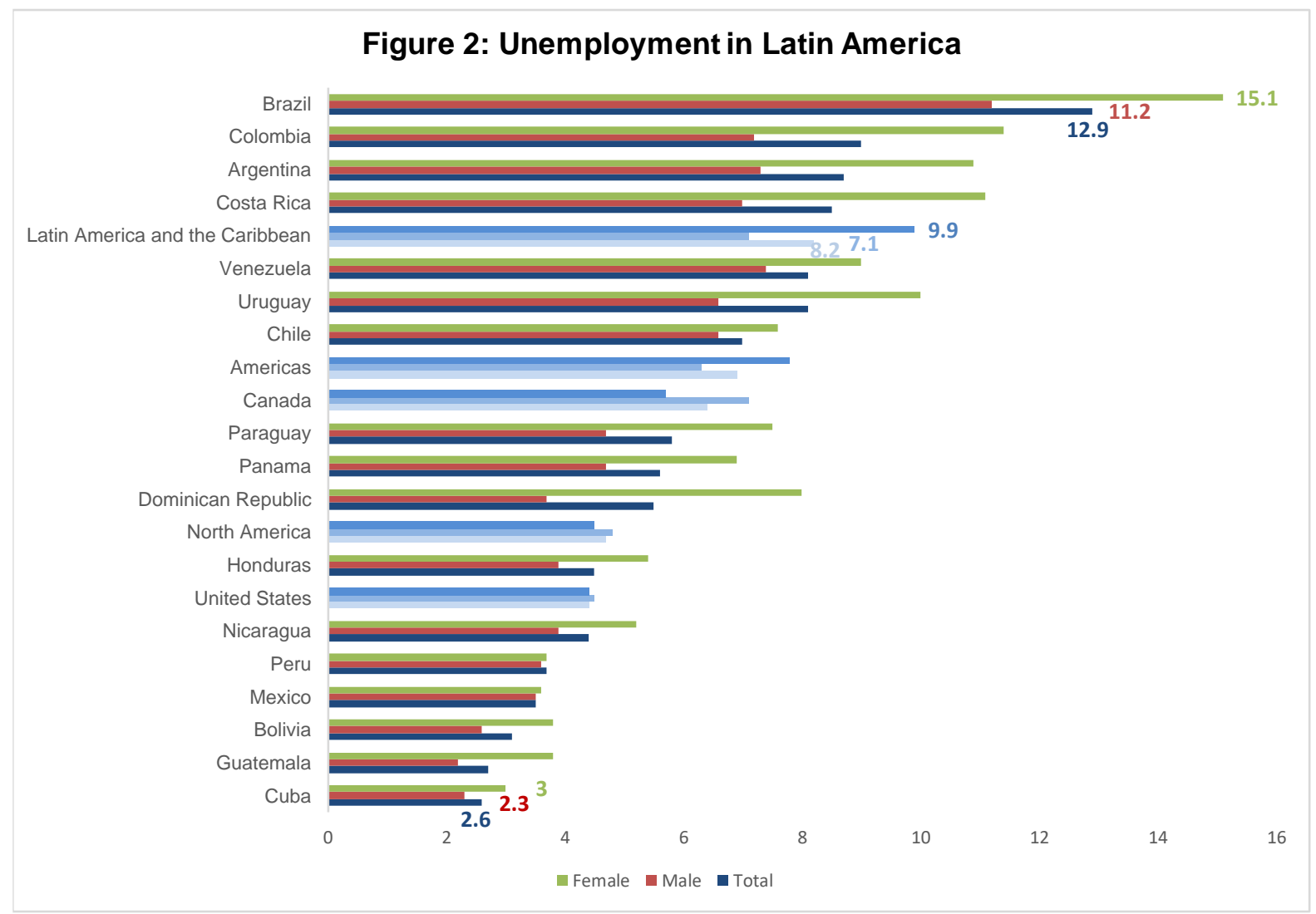

Notes: Data estimates for 2017 provided by the International Labor Organization (ILO) STAT available at <http://www.ilo.org/ilostat> 
Figure 3: Informal Employment in Latin America

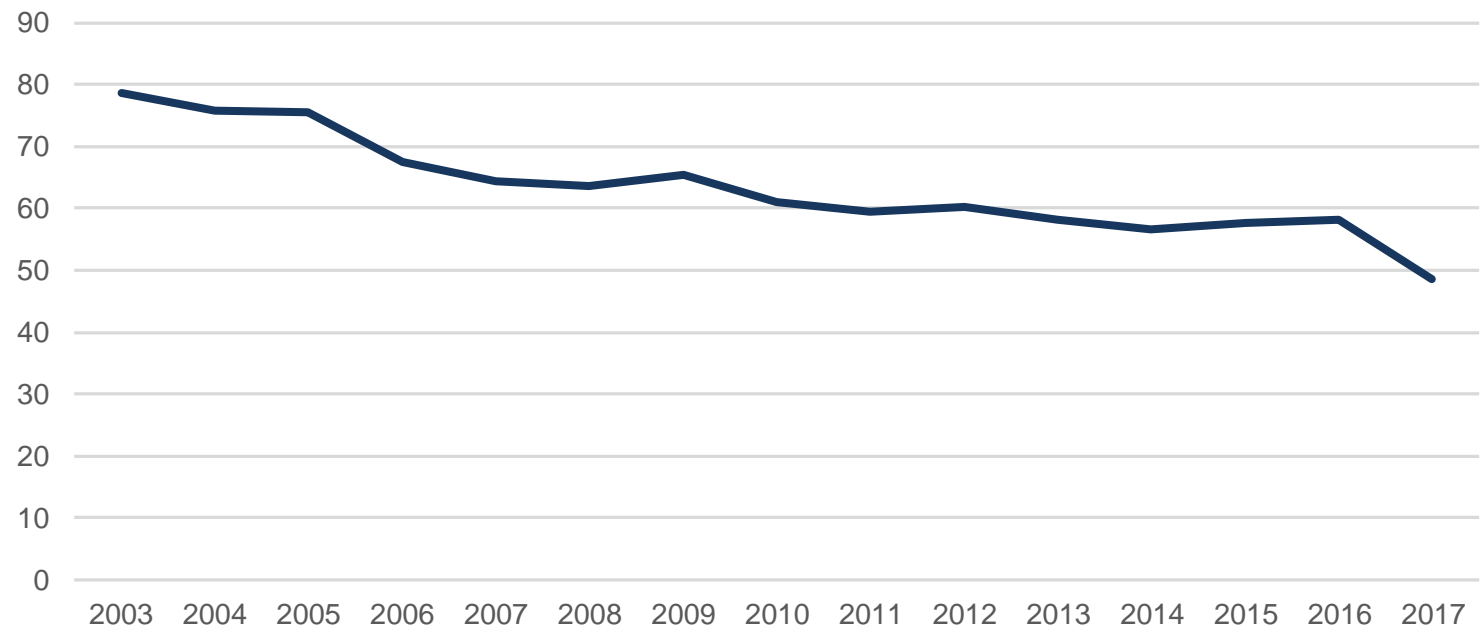

Notes: Informal employment and informal sector as a percent of employment from 1997 to 2016 . Data provided by the International Labor Organization (ILO) Statistics available at <http://www.ilo.org/ilostat>

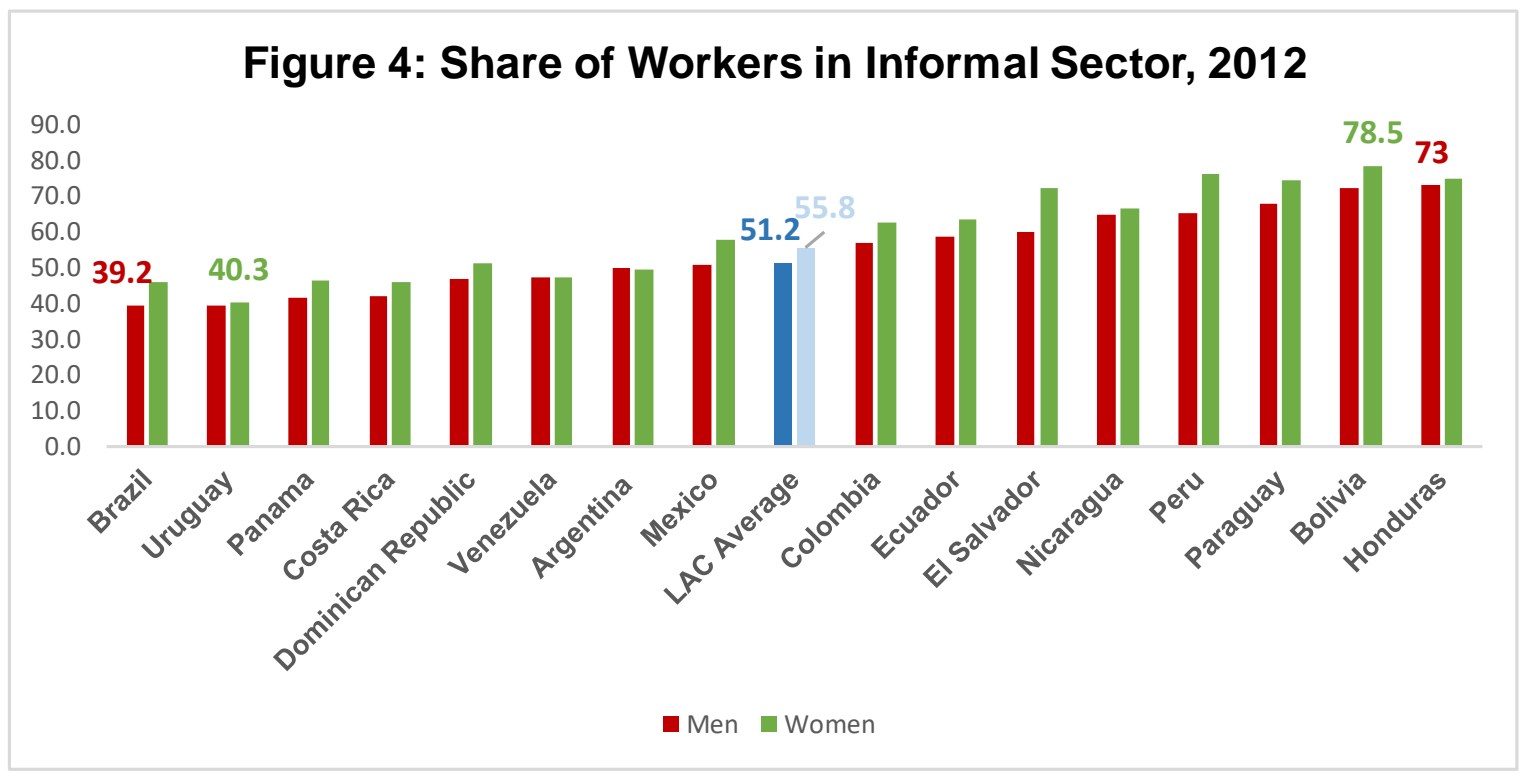

Note: The International Labor Organization (ILO) considers in its definition of informal employment, all workers of the informal sector and informal workers outside the informal sector. Employment in the informal sector comprises all persons who, during a given reference period, were employed in at least one informal sector enterprise which consists of: It is not constituted as a legal entity separate from its owners, and; It is owned and controlled by one or more members of one or more households, and; It is not a quasi-corporation (it does not have a complete set of accounts, including balance sheets). It must be producing a good or serivce, and excludes households employing paid domestic workers. Informal employment outside of the informal sector comprises persons who in their main or secondary jobs were: own-account workers engaged in the production of goods exclusively for own final use by their household; contributing family workers, irrespective of whether they work in formal or informal sector enterprises; Employees holding informal jobs, whether employed by formal sector enterprises, informal sector enterprises, or as paid domestic workers by households. <http://www.ilo.org/ilostat-files/Documents/description_IFL_EN.pdf> Note 2: Data provided by ILOSTAT <http://www.ilo.org/ilostat> 


\section{Figure 5: Labor Productivity in Latin America}

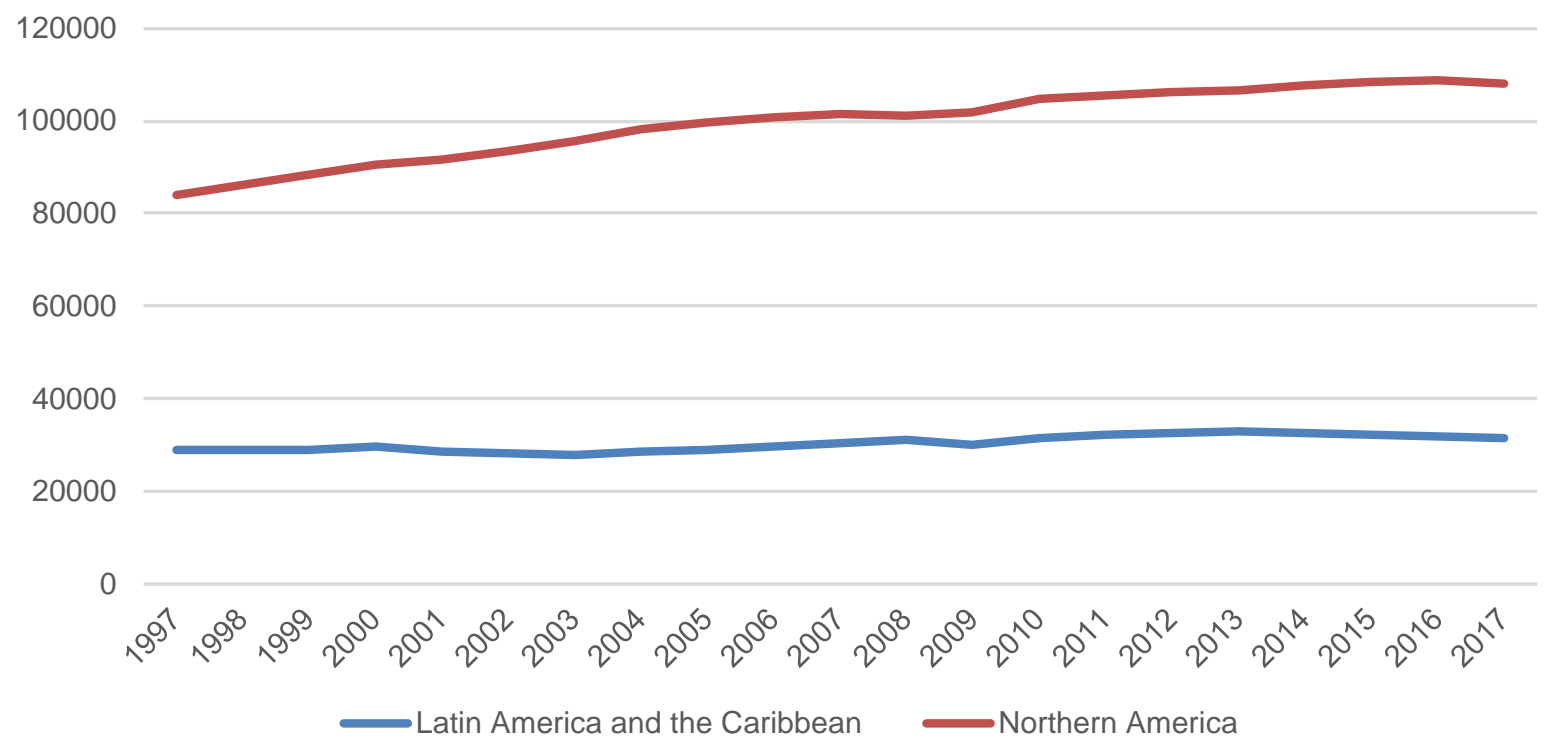

Notes: International Labor Organization (ILO) estimates for Nov. 2017 measured as output per worker (GDP constant 2011 international \$ in PPP 1997-2017). Data provided by the ILO Stat page <http://www.ilo.org/ilostat>

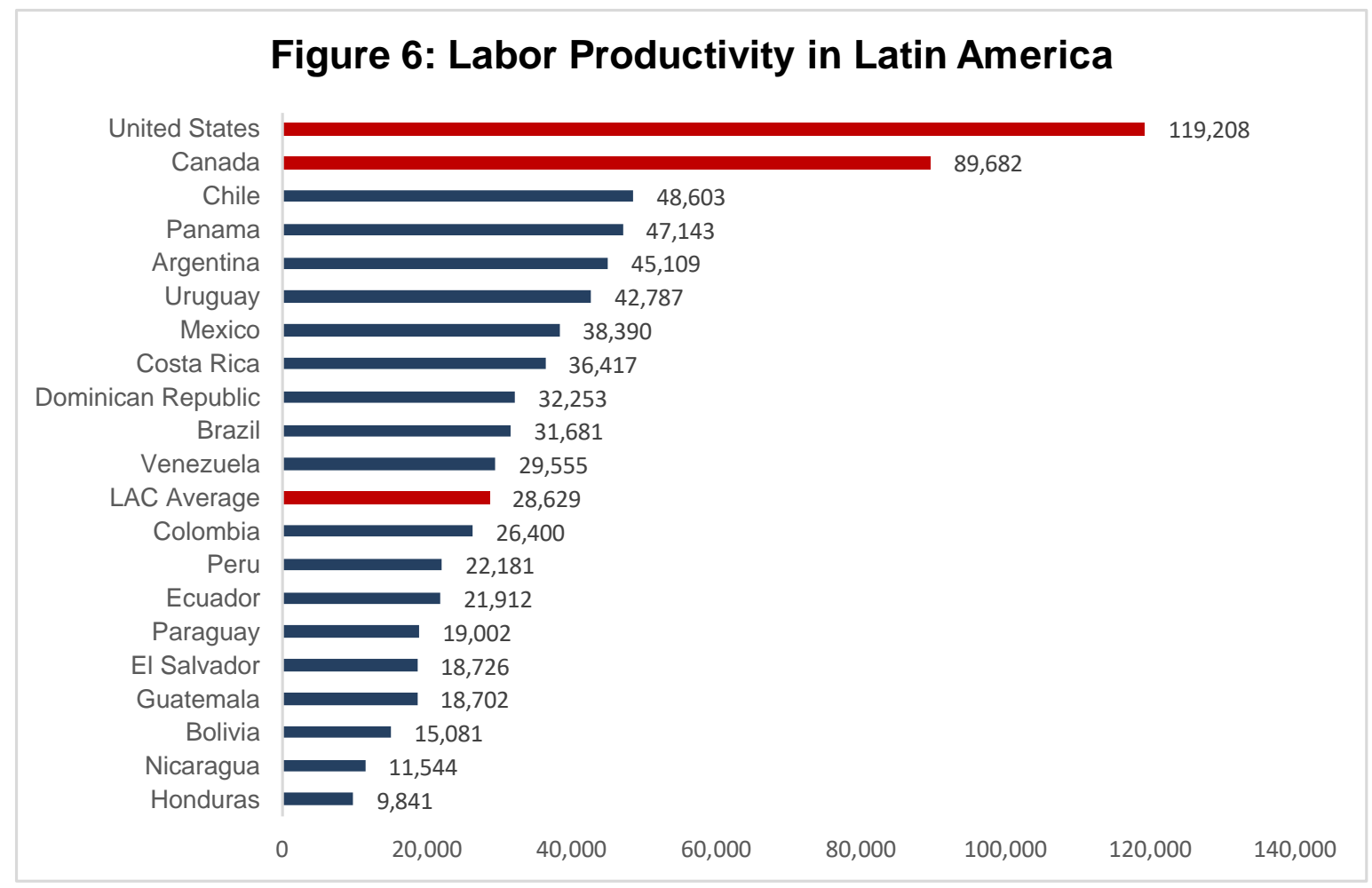

Notes: International Labor Organization (ILO) estimates for Nov. 2017 measured as output per worker (GDP constant 2011 international \$ in PPP). Data provided by the ILO Stat page <http://www.ilo.org/ilostat> 


\section{Figure 7: Levels of the Gini Coefficient}

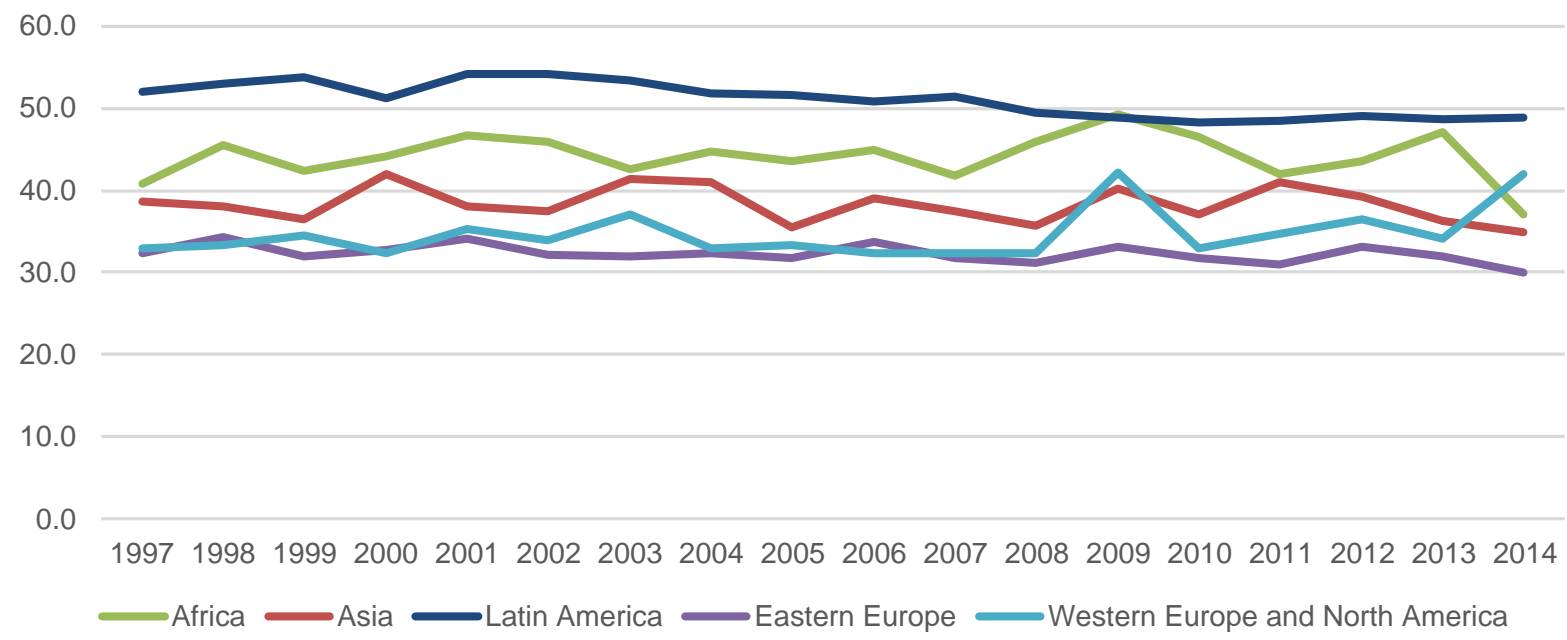

Notes: This dataset consists only of the Gini coefficients that have been calculated from actual household surveys by Branko Milanovic Originally at World Bank, Research Department October 2016. The dataset covers 160 countries from 1950 to 2015 and is available at <https://www.gc.cuny.edu/Page-Elements/Academics-Research-CentersInitiatives/Centers-and-Institutes/Stone-Center-on-Socio-Economic-Inequality/Core-Faculty,-Team,-and-Affiliated-LISScholars/Branko-Milanovic/Datasets>

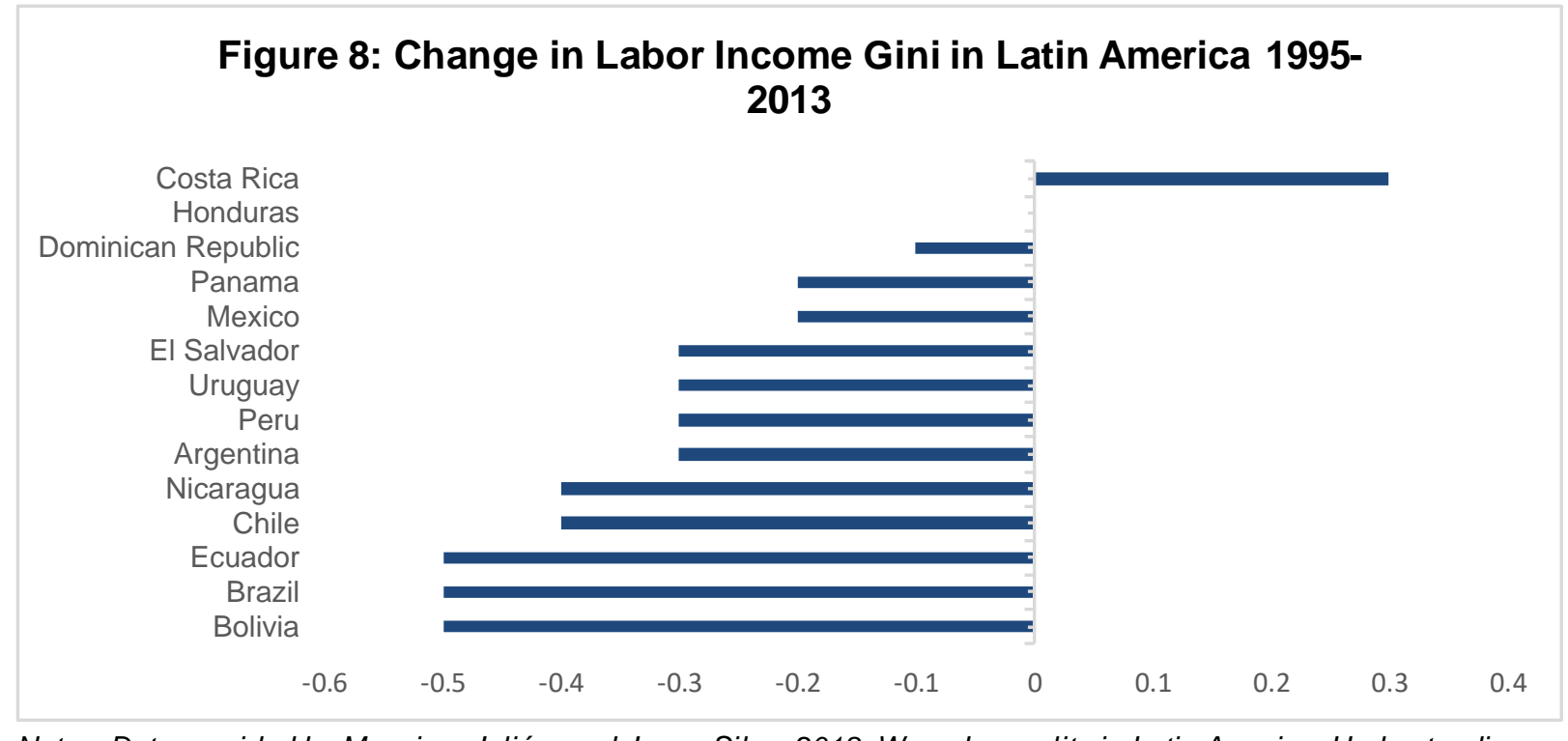

Notes: Data provided by Messina, Julián, and Joana Silva. 2018. Wage Inequality in Latin America: Understanding the Past to Prepare for the Future. Latin American Development Forum. Washington, DC: World Bank. doi:10.1596/978-1-4648-1039-8. License: Creative Commons Attribution CC BY 3.0 IGO 
Figure 9: Employment Protection Legislation Index in Latin America

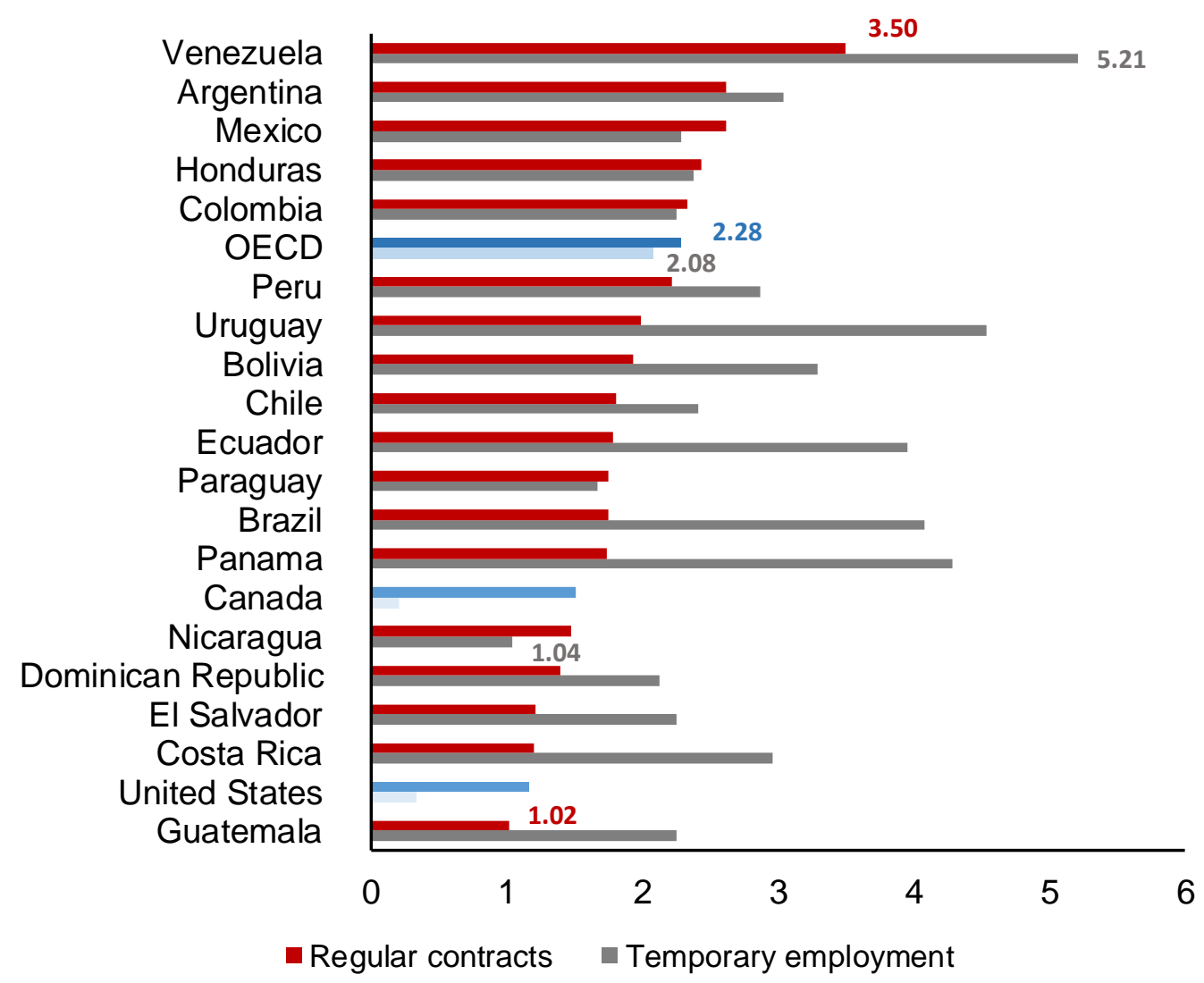

Notes: International Labor Organization: Canada, U.S., OECD (2013); Argentina, Bolivia, Brazil, Chile, Colombia, Costa Rica, Dominican Republic, Ecuador, El Salvador, Guatemala, Honduras, Mexico, Nicaragua, Panama, Paraguay, Peru, Uruguay, Venezuela (2014). Data provided by ILOSTAT <http://www.ilo.org/ilostat> 
Figure 10: Changes in EPL in Latin America

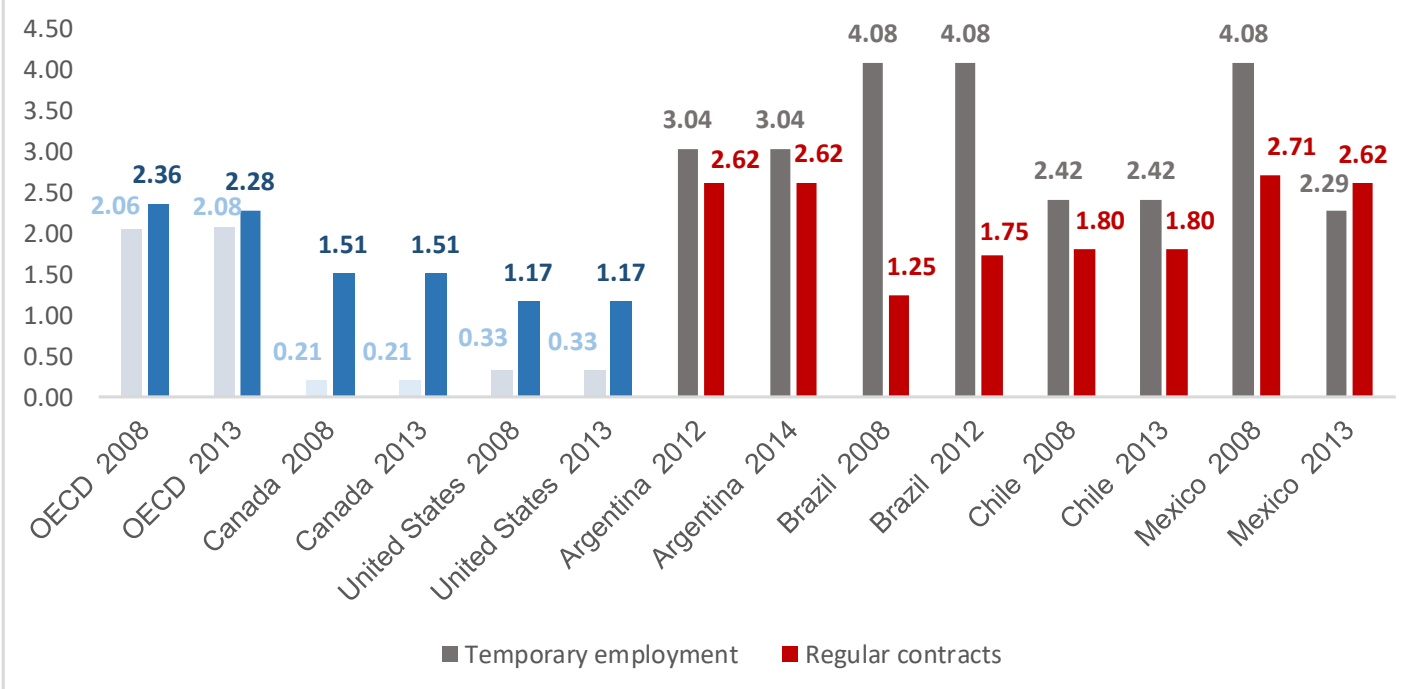

Notes: Data provided by the International Labor Organization Statistics (ILOSTAT) available at <http://www.ilo.org/ilostat> 


\section{Figure 11: Ratio of minimum to mean wages in Latin America}

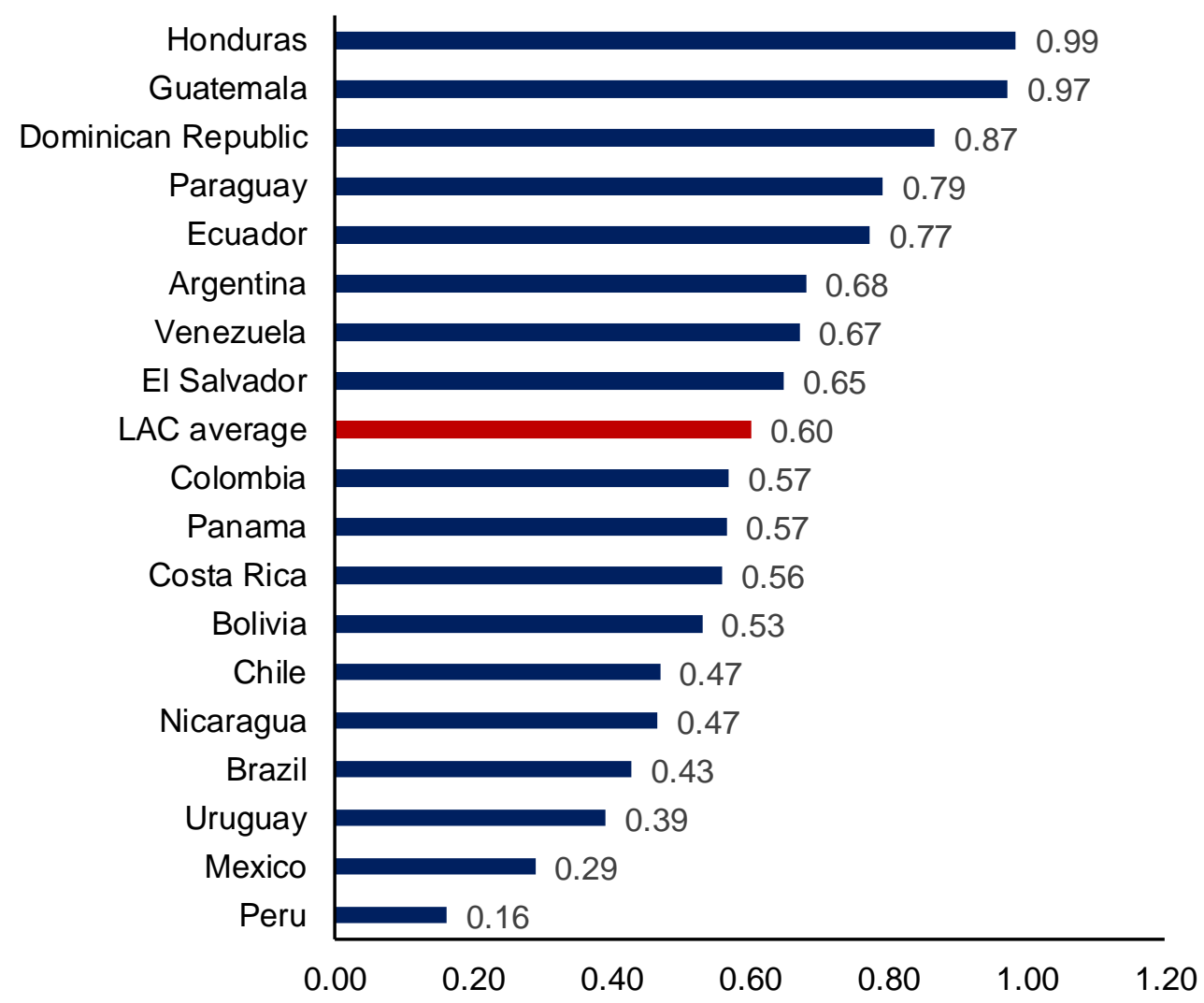

Notes: Data provided by the International Labor Organization Statitstics (ILOSTAT) $<$ <ttp://www.ilo.org/ilostat>. Panama, Venezuela (2012); Honduras, Guatemala, El Salvador, Nicaragua, Uruguay (2013); Argentina, Bolivia (2014); Brazil, Dominican Republic, Ecuador (2015); Costa Rica, Colombia (2016); and the OECD database <https://data.oecd.org/> : Chile, Mexico (2016) 


\section{Figure 12: Ratio of minimum to median}

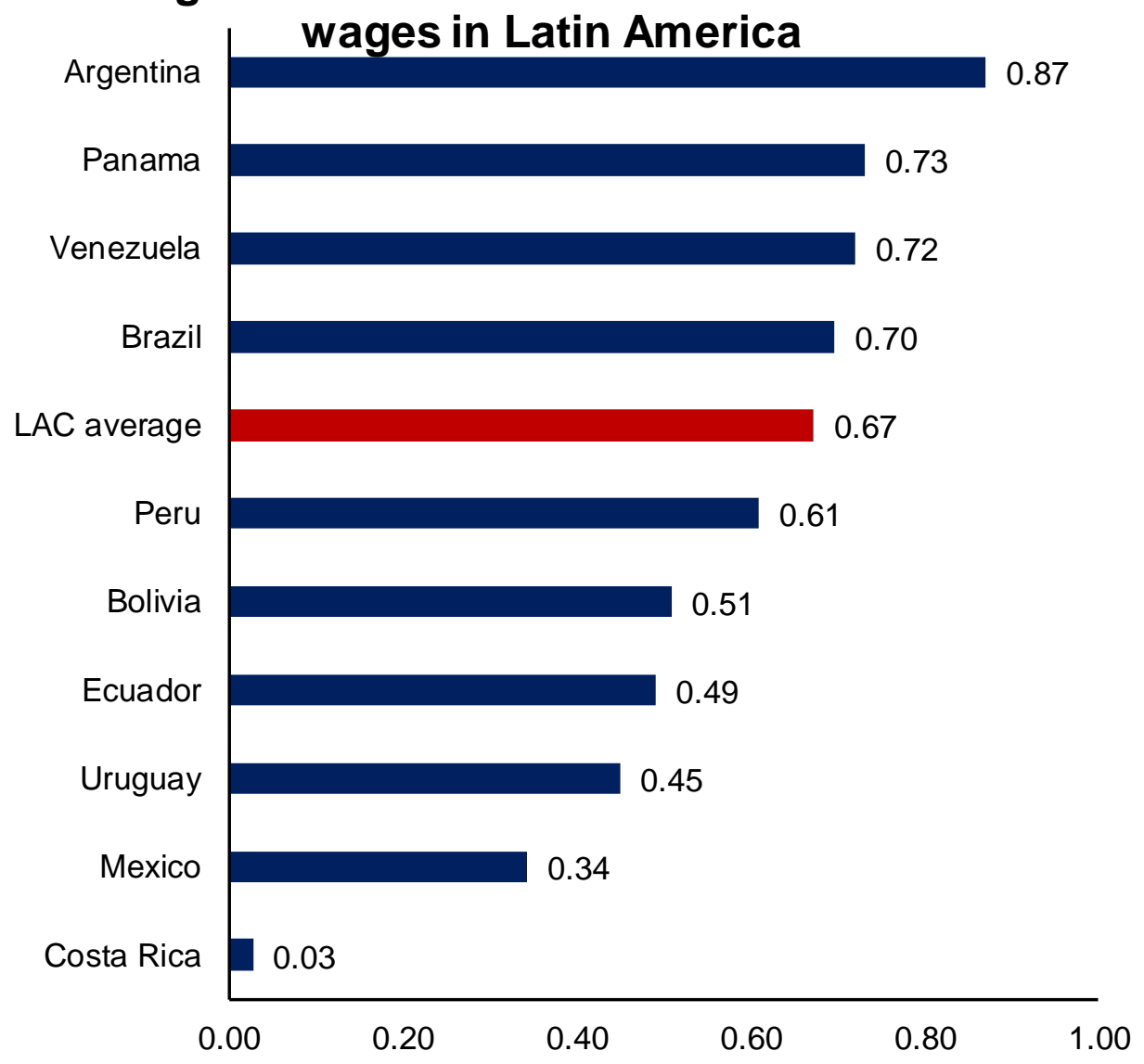

Notes: Data provided by the International Labor Organization Statitstics (ILOSTAT)

$<$ <ttp://www.ilo.org/ilostat> Costa Rica, Brazil (2010); Peru, Venezuela (2011); Paraguay, Uruguay (2014); Argentina, Bolivia, Ecuador (2015) 


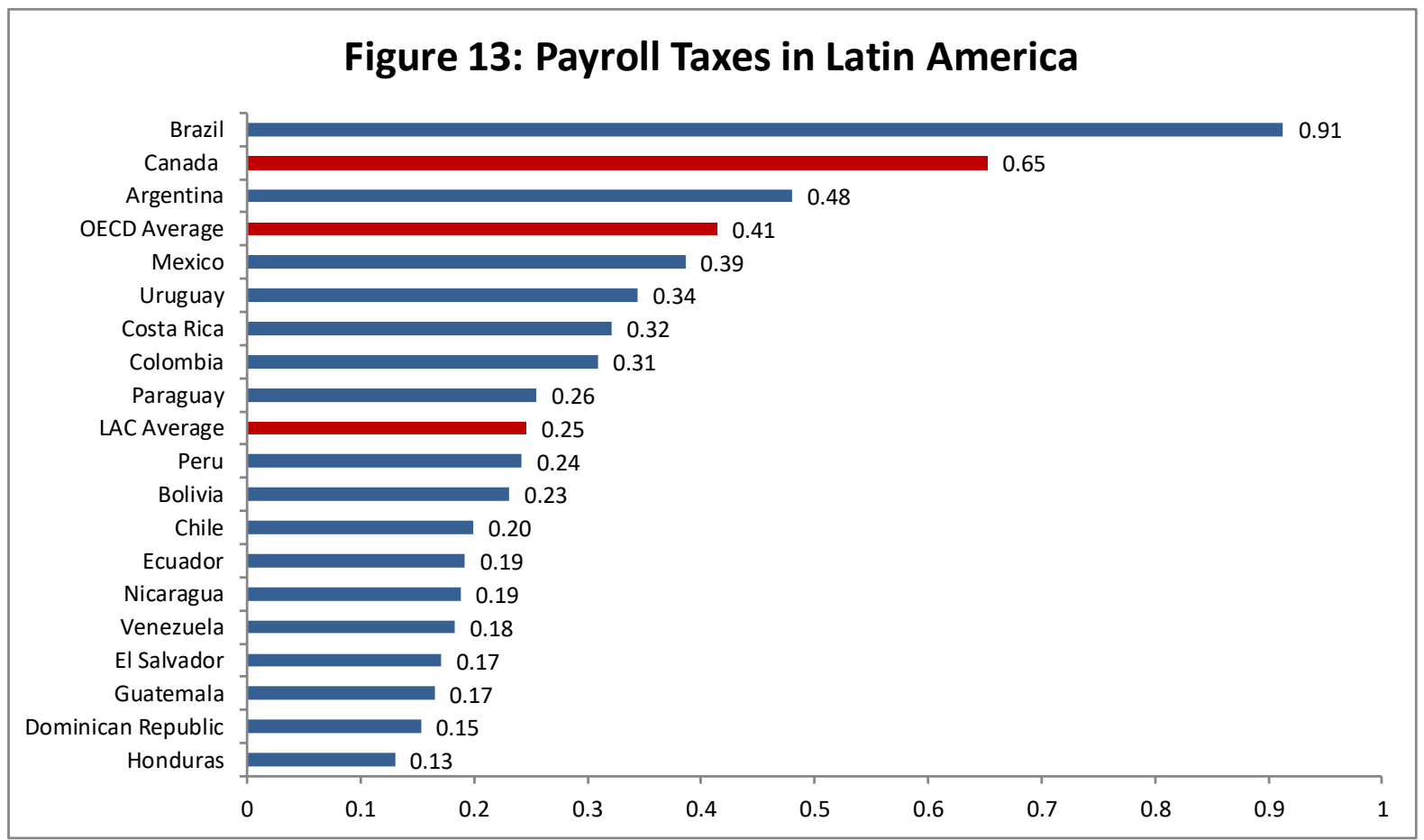

Notes: Data provided by Government Agencies; ECLAC; KPMG IDB WORKING PAPER SERIES No. IDB-WP-334 "Employment and Taxes in Latin America: An Empirical Study of the Effects of Payroll, Corporate Income and Value-Added Taxes on Labor Outcomes" Eduardo Lora and Johanna Fajardo average 1985-2009 (2012) <https://papers.ssrn.com/sol3/papers.cfm?abstract_id=2207238> ; OECD database 
Figure 14: Gross Replacement Rate in Latin America

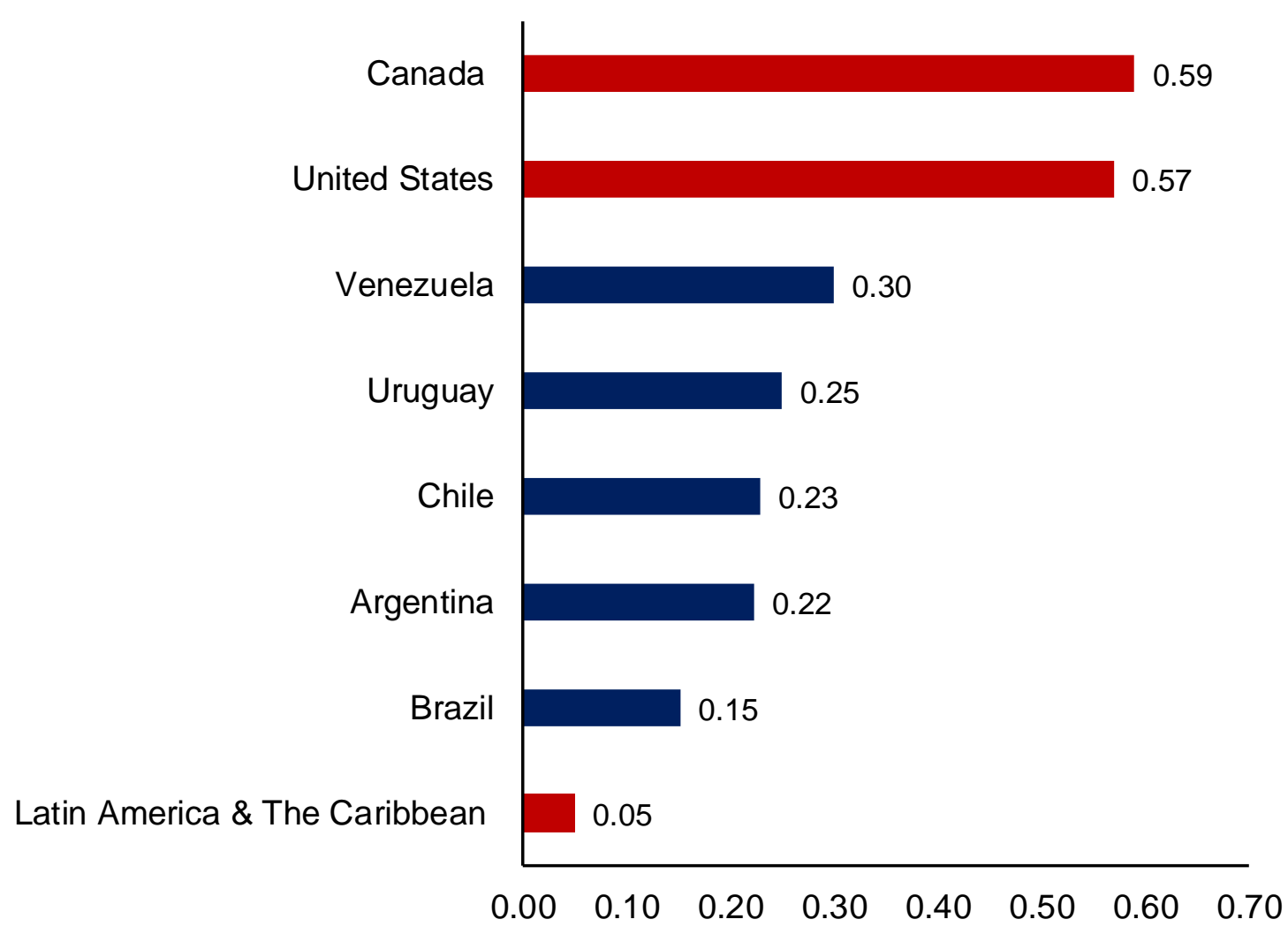

Notes: Data provided by Schindler, Martin and Mariya Aleksynska (2011) "Labor Market Regulations in Low-, Middle- and High-Income Countries : A New Panel Database". IMF Working Paper available at https://www.imf.org/external/pubs/cat/longres.aspx?sk=25015.0; "Van Vliet, Olaf and Koen Caminada. Unemployment replacement rates dataset among 34 welfare states 1971-2009: An update, extension and modification of Scruggs' Welfare State Entitlements Data Set" available at http://www.law.leidenuniv.nl/org/fisceco/economie/hervormingsz/datasetreplacementrates.html: Canada, USA (2009) 


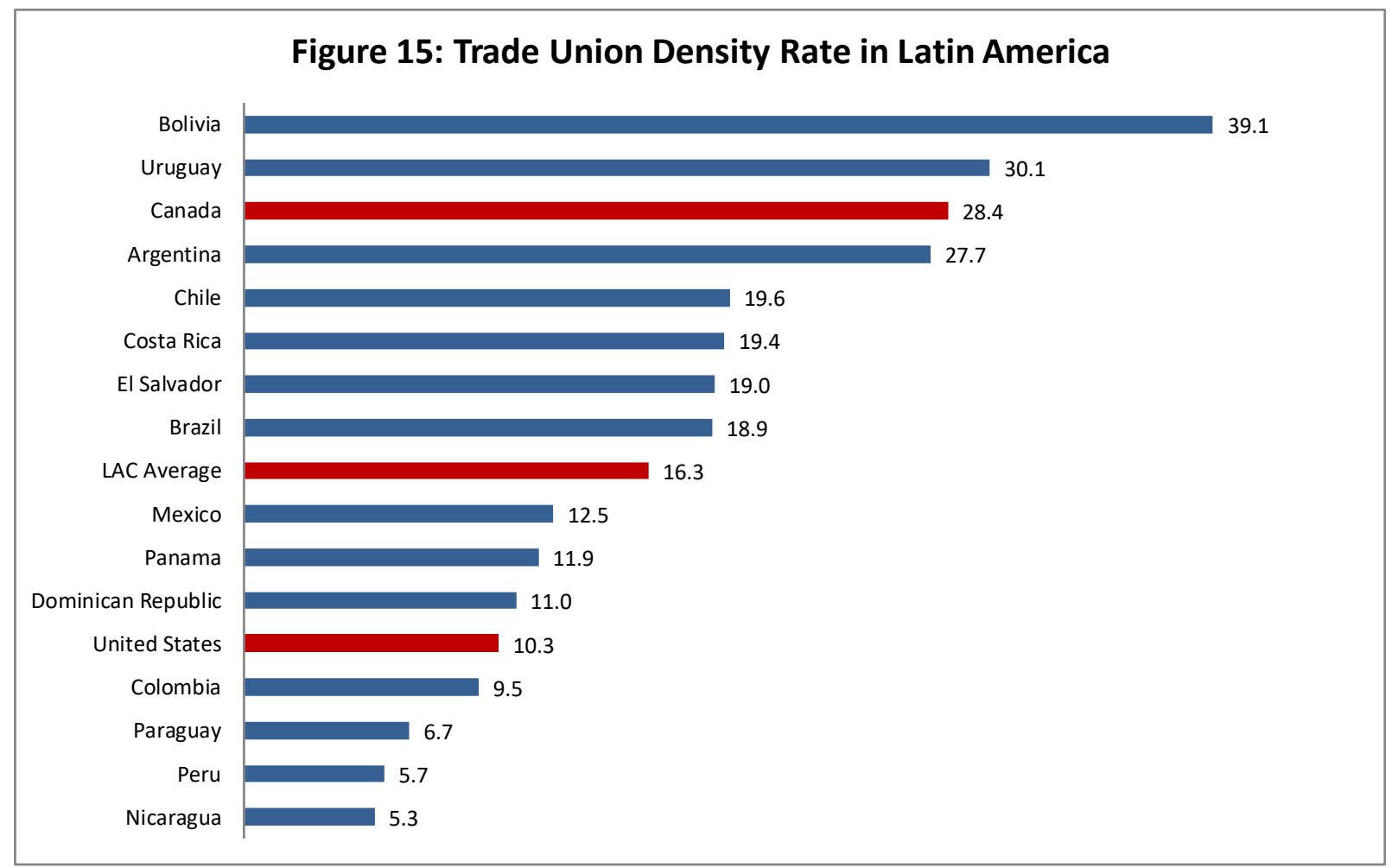

Notes: International Labor Organization data compilation effort (including an annual questionnaire and numerous special enquiries), with contributions from J. Visser. Latest data available for all countries (2016), Argentina, Bolvia (2014), Paraguay (2015), Uruguay (2013). Trade union density rate conveys the number of union members who are employees as a percentage of the total number of employees. It excludes union members who are not in paid employment (self-employed, unemployed, retired, etc.) available at <http://www.ilo.org/ilostat> 


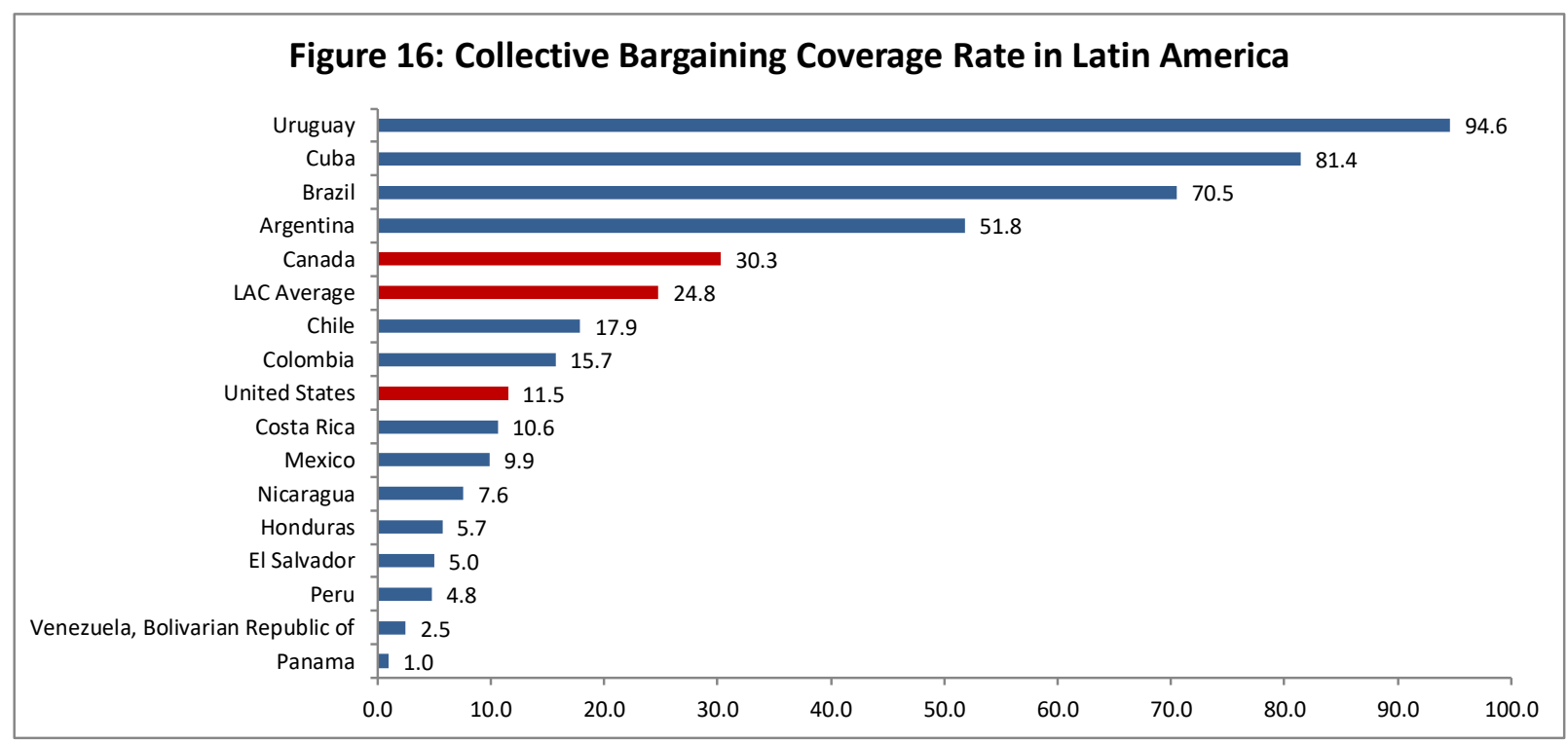

Notes: The collective bargaining coverage rate conveys the number of employees whose pay and/or conditions of employment are determined by one or more collective agreement(s) as a percentage of the total number of employees. Collective bargaining coverage includes, to the extent possible, workers covered by collective agreements in virtue of their extension. Collective bargaining coverage rates are adjusted for the possibility that some workers do not have the right to bargain collectively over wages (e.g. workers in the public services who have their wages determined by state regulation or other methods involving consultation), unless otherwise stated in the notes. Data prodivded by the International Labor Organization (ILO)in effort with contributions from J. Visser. All countrys in dataset (2016); Cuba (2008), Honduras (2007), Nicaragua (2010), Paraguay (2015), Venezuela (2012) available at <http://www.ilo.org/ilostat>

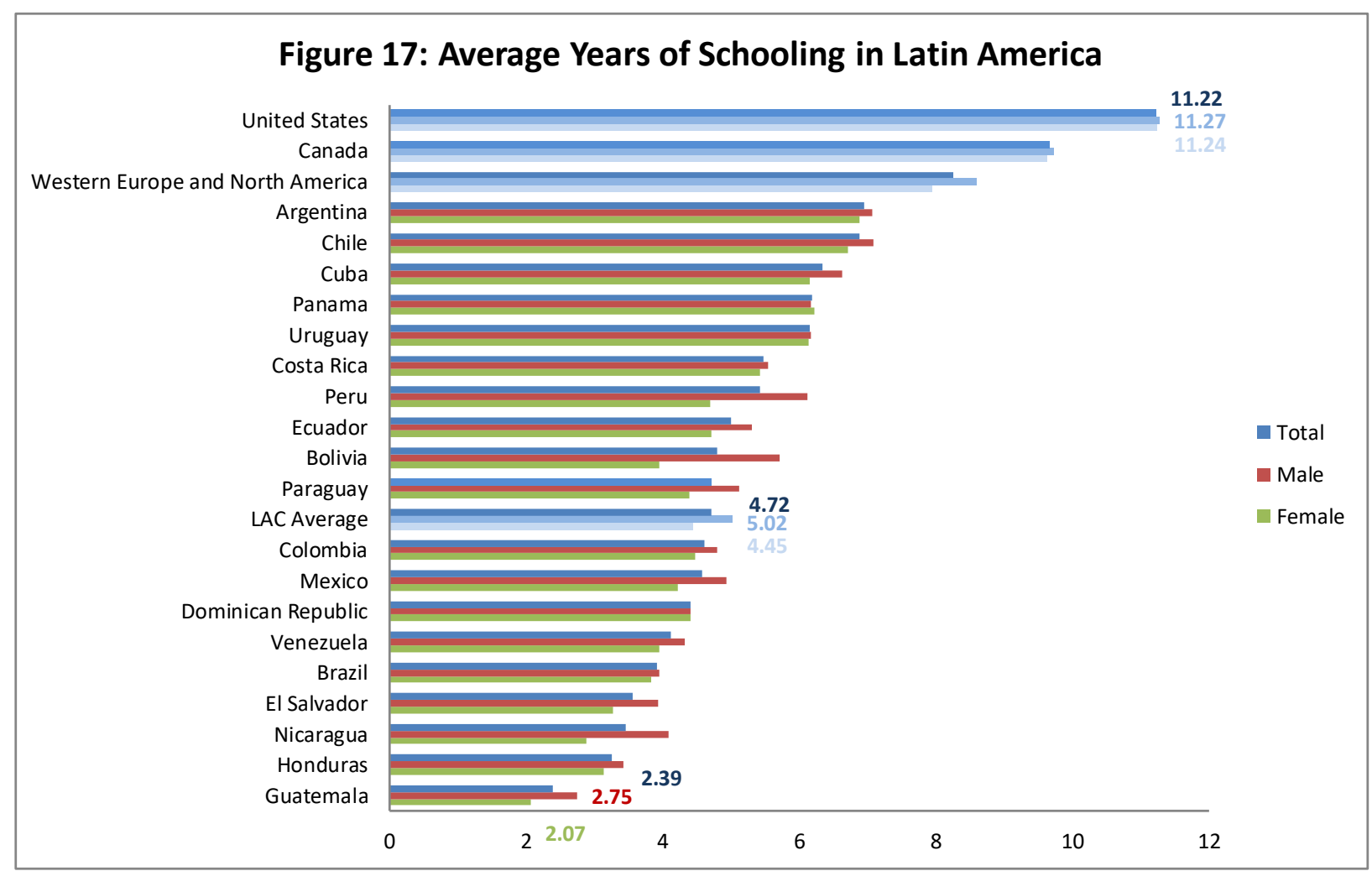

Notes: Data provided by Barro \& Lee Educational Attainment Dataset Averages from $1985-2010$ for individuals of 25+ years of age contained in the Quality of Government Dataset 2017 Teorell, Jan, Stefan Dahlberg, Sören Holmberg, Bo Rothstein, Anna Khomenko \& Richard Svensson. 2017. The Quality of Government Standard Dataset, version Jan17. University of Gothenburg: The Quality of Government Institute, http://www.qog.pol.gu.se doi:10.18157/QoGStdJan17 


\section{Figure 18: Change in Return to Skill (completed tertiary vs. primary or less) in Latin America 1995-2013}
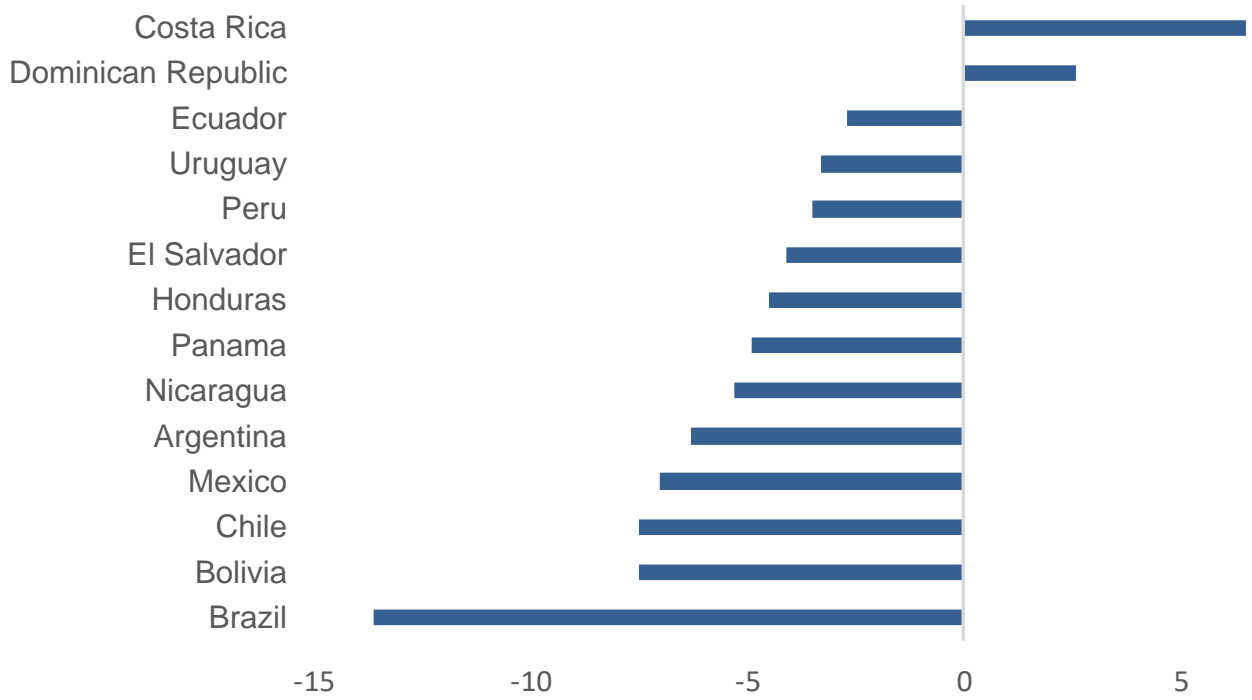

Notes: Data provided by Messina, Julián, and Joana Silva. 2018. Wage Inequality in Latin America: Understanding the Past to Prepare for the Future. Latin American Development Forum. Washington, DC: World Bank. doi:10.1596/978-1-4648-1039-8. License: Creative Commons Attribution CC BY 3.0 IGO 


\section{Figure 19: Gender Wage Gap in Latin America}

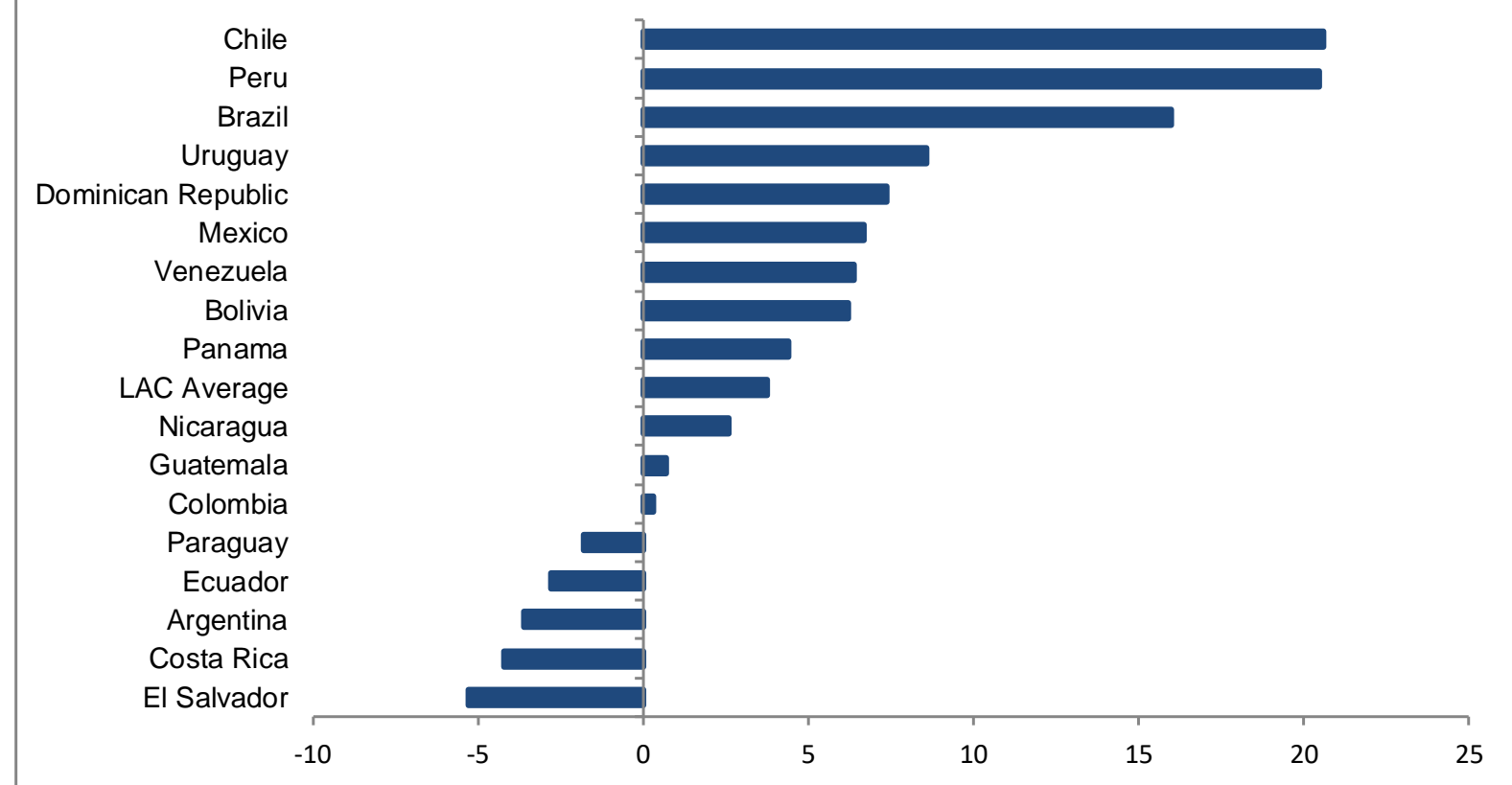

Notes: Data provided by the International Labor Organization Statistics (ILOSTAT) based on Integrated Household Surveys, and Labor Force Surveys, and available at available at <http://www.ilo.org/ilostat> . Honduras, El Salvador, Argentina, Paraguay, Guatemala, Nicaragua, Panama, Bolivia, Mexico, Uruguay, Brazil, and Peru (2014); Costa Rica, Ecuador (2016); Colombia, Dominican Republic (2015); Chile (2013); Venezuela (2006). The gender wage gap is unadjusted and is calculated as the difference between average earnings of men and average earnings of women expressed as a percentage of average earnings of men. 